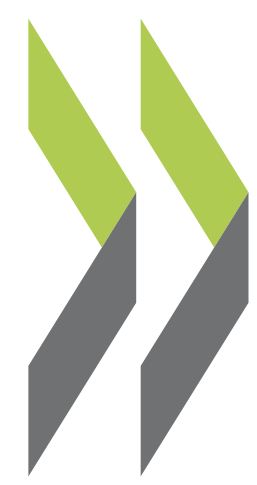

OECD Economics Department Working Papers No. 898

Promoting Infrastructure Development in Brazil
Annabelle Mourougane,

Mauro Pisu 


\section{Unclassified}

ECO/WKP(2011)67

Organisation de Coopération et de Développement Économiques

Organisation for Economic Co-operation and Development

21-Oct-2011

ECONOMICS DEPARTMENT

English - Or. English

PROMOTING INFRASTRUCTURE DEVELOPMENT IN BRAZIL

ECONOMICS DEPARTMENT WORKING PAPER No. 898

By Annabelle Mourougane and Mauro Pisu

All OECD Economics Department Working Papers are available on the OECD Intranet website at www.oecd.org/eco/workingpapers

JT03309600

Document complet disponible sur OLIS dans son format d'origine

Complete document available on OLIS in its original format 


\section{ABSTRACT/RESUME}

\section{Promoting infrastructure development in Brazil}

Brazil under-invested in infrastructure for over three decades, and infrastructure investment rates have come up only slowly since 2007. Infrastructure needs are sizeable in almost all sectors. It is likely that at its current stage of development the country will benefit from large pay-offs from infrastructure spending. Against this background, the Brazilian authorities have put in place a large infrastructure plan named Growth Acceleration Programme (Programa de aceleração do crescimento, PAC). This programme has been rightly protected from the fiscal cuts announced in early 2011. Nevertheless, some changes to the policy and regulatory framework could be introduced to make public investment more cost-efficient and to foster private participation. In particular:

- The second stage of PAC needs to focus on completing the most worthwhile programmes. In addition, the public-private partnership framework should be streamlined.

- In most areas, the regulatory framework is working well, but sectors are at different stages of development. Despite important institutional changes in recent years, policy capture is sometimes still influencing some federal and many state regulatory agency decisions.

- In spite of some recent progress, frequent disputes appear to delay some infrastructure projects, especially in the energy sector. The main challenge in this area is to hasten the licensing process, while continuing to put appropriate emphasis on environmental and social protection.

- Reforms have been implemented in individual network industries, but there is still some room to inject competition in fixed-line telecommunications and to prevent product cross-subsidisation in the electricity sector. Concession contracts in both roads and rail could be refined to foster private investment in maintenance and network expansion. In water and sanitation, where investments are the most needed, smaller municipalities should be encouraged to invest and form consortia to reap economies of scale.

This Working Paper relates to the 2011 OECD Economic Review of Brazil 2011 (www.oecd.org/eco/surveys/Brazil).

JEL classification codes: H54; H81; H43; K23

Keywords: Brazil; infrastructure; PPPs; regulatory framework 


\section{Promouvoir le développement des infrastructures au Brésil}

Le Brésil a peu investi en infrastructure ces trente dernières années, et les dépenses d'équipement dans ce domaine n'augmentent que lentement depuis 2007. Les besoins sont considérables dans presque tous les secteurs. Au stade actuel de son développement, le pays a sans doute tout intérêt à engager des dépenses d'infrastructure. C'est pourquoi les autorités brésiliennes ont mis en place un vaste plan de développement de l'infrastructure, appelé Programme d'accélération de la croissance (Programa de aceleração do crescimento, PAC). Ce programme a été, à juste titre, épargné par les coupes budgétaires annoncées début 2011. Néanmoins, certaines modifications pourraient être apportées au cadre stratégique et réglementaire afin de rendre l'investissement public plus rentable et de stimuler la participation du secteur privé. En particulier :

- La deuxième phase du PAC doit être centrée sur l'achèvement des programmes les plus importants. Par ailleurs, le cadre de partenariat public-privé devrait être simplifié.

- Dans la plupart des domaines, le cadre réglementaire fonctionne bien, mais les secteurs en sont à des stades de développement différents. Malgré les importantes réformes institutionnelles de ces dernières années, la captation par des intérêts particuliers continue parfois d'influer sur certaines décisions fédérales et sur des décisions de nombreux organismes de réglementation des États.

- Malgré des progrès récents, de fréquents conflits paraissent retarder certains projets d’infrastructure, en particulier dans le secteur de l'énergie. La principale difficulté dans ce domaine consiste à accélérer le processus d'octroi de licences, tout en continuant de mettre l'accent comme il convient sur la protection sociale et environnementale.

- Des réformes ont été mises en œuvre dans certains secteurs de réseau, mais l'on pourrait encore faire jouer davantage la concurrence dans la téléphonie fixe et éviter les péréquations tarifaires dans le secteur de l'électricité. Les contrats de concession, tant pour les routes que pour le rail, pourraient être affinés afin de favoriser l'investissement privé à la fois dans l'entretien et dans l'extension des réseaux. Dans le domaine de l'eau et de l'assainissement, où l'insuffisance des investissements est la plus importante, les petites municipalités devraient être encouragées à investir et à former des consortiums afin de profiter des économies d'échelle réalisables.

Ce document de travail se rapporte à l’Étude économique de l’OCDE du Brésil 2011. (www.oecd.org/eco/etudes/Bresil).

Classification JEL : H54 ; H81 ; H43 ; K23

Mots clefs : Brésil; infrastructure ; PPPs ; cadre réglementaire

Copyright $₫$ OECD, 2011. All rights reserved. Application for permission to reproduce or translate all, or part of, this material should be made to: Head of Publications Service, OECD, 2 rue André-Pascal, 75775 PARIS CEDEX 16, France. 


\section{Table of contents}

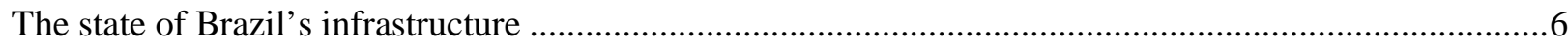

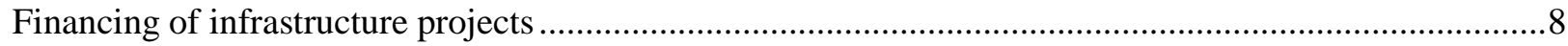

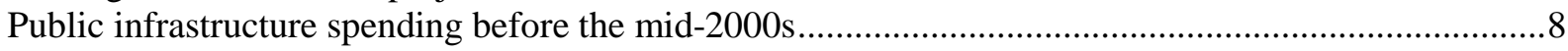

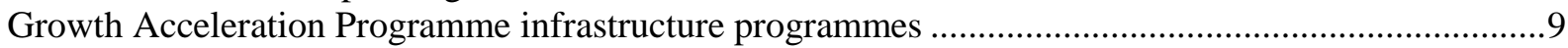

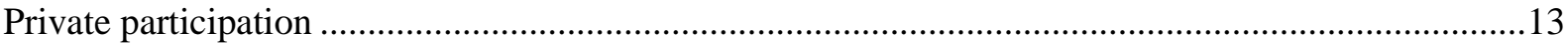

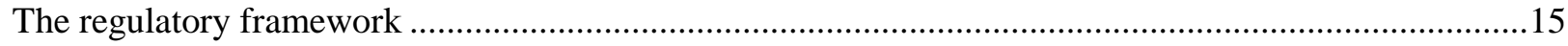

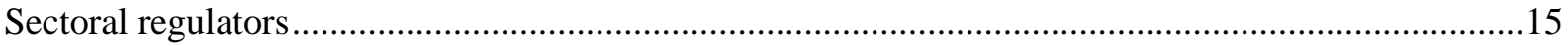

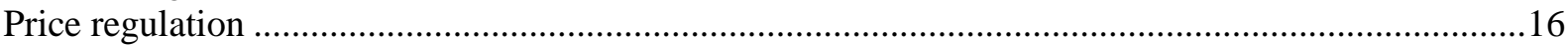

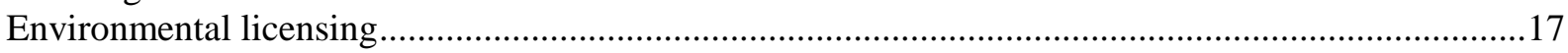

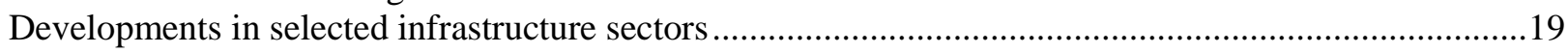

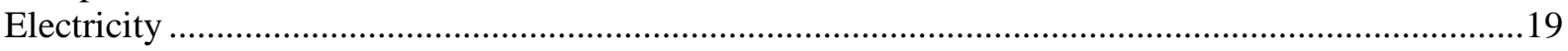

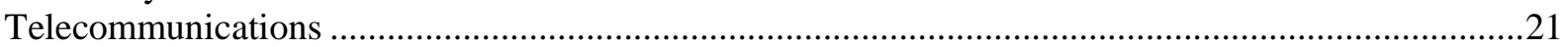

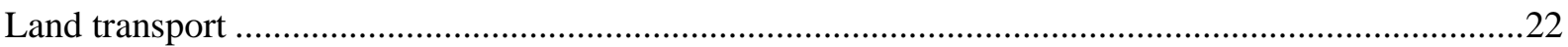

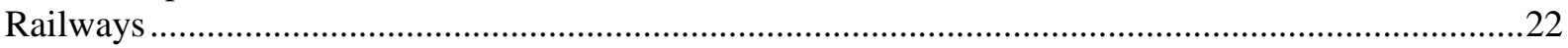

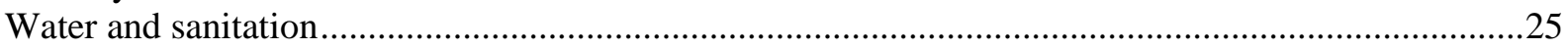

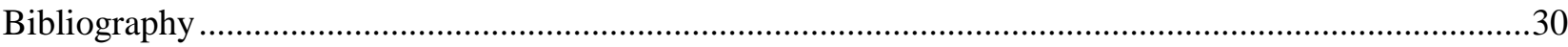

\section{Boxes}

1. The Growth Acceleration Programme .........................................................................................11

2. The experience of Chile with the Least Present Value of the Revenues mechanism .......................25

\section{Tables}

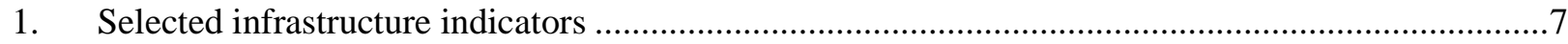

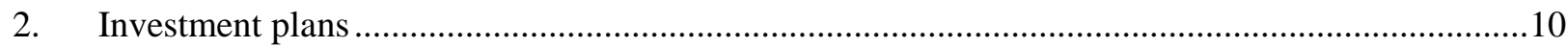

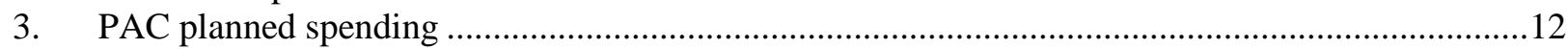

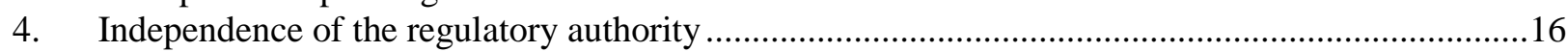

5. Powers of regulatory authorities in infrastructure industries...................................................17

6. Degree of price regulation in infrastructure industries ..................................................................18

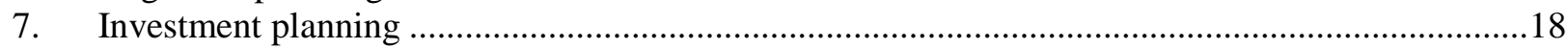




\section{Figures}

1. Percentage of sewage collected by states grouped by regions..........................................................

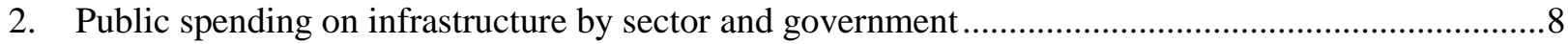

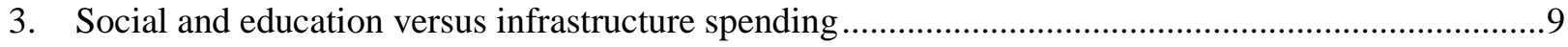

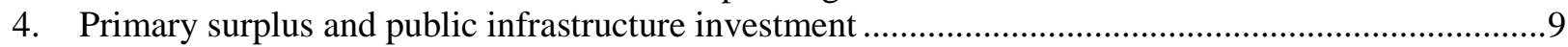

5. Long-term effect of the PAC programme on the public deficit.......................................................13

6. Total investment in private projects by sector .................................................................................13

7. Total investment in private projects in energy, telecommunications and

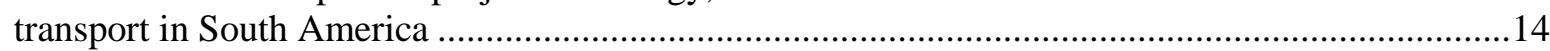

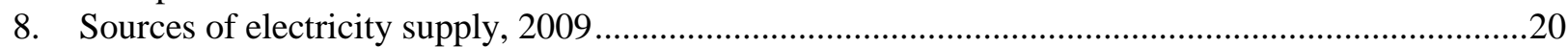

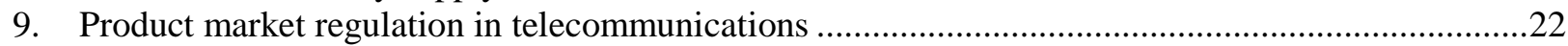

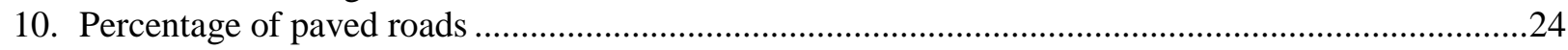

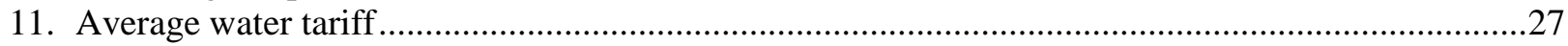

This document and any map included herein are without prejudice to the status of or sovereignty over any territory, to the delimitation of international frontiers and boundaries and to the name of any territory, city or area. 


\title{
Promoting infrastructure development in Brazil
}

\author{
By Annabelle Mourougane and Mauro Pisu ${ }^{1}$
}

\begin{abstract}
Large investment in infrastructure will be essential for Brazil to achieve strong and sustainable growth over an extended period of time. Infrastructure development is also associated with reduced income inequality and can thus be a powerful tool for poverty reduction (López, 2004). It improves connectivity, lowers transport costs for both firms and the population and facilitates access to basic education and health services. Empirical evidence also points to larger pay-offs to investment in infrastructure at earlier stages of development (Estache and Fay, 2007; Straub, 2008; Égert et al., 2009). According to Morgan Stanley (2010), infrastructure investment of about 4\% of GDP per year over 20 years would be needed for Brazil to catch up to the infrastructure levels of Chile, the current leader in South America. At the same time, important events such as the 2014 World Cup and the 2016 Olympics, as well as the exploitation of the pre-salt oil reserves, offer a window of opportunity for undertaking needed infrastructure developments.

This paper reviews changes to policies and institutions to make the most of these opportunities and boost investment in infrastructure in the coming years. After briefly reviewing the current state of infrastructure in Brazil, this paper discusses the financing of infrastructure development. It then turns to an examination of the regulatory framework and compares it with those of OECD countries, before concentrating on sectoral developments. Several network industries are examined in turn, namely electricity, telecommunications, road and rail transportation, and water and sanitation.
\end{abstract}

\section{The state of Brazil’s infrastructure}

Brazil's infrastructure is in a relatively good shape compared to what can be observed in other South American countries (Table 1). The comparison is less favourable compared to other regions in the world. While there has been a catch-up in some sectors such as telecommunications, the infrastructure gap vis-à-vis East Asia has narrowed somewhat, but remains considerable (Calderón and Servén, 2004). Access to electricity is now widespread, though some remote areas still have to be connected to the grid. In 2009, the electrification rate was $99.5 \%$ in urban areas and $88 \%$ in rural areas. By contrast, the country underperforms in terms of access to improved sanitation, while the percentage of mobile cellular subscribers is also low.

1. Senior Economist and Economist in the OECD Economics Department. This paper reports on background work for the 2011 OECD Economic Survey of Brazil. The author is grateful for the valuable comments received on earlier drafts from Andrew Dean, Robert Ford and Peter Jarrett as well as for comments from Andrea Goldstein and Sebastian Nieto Parra and discussions with officials of the Brazilian government. Special thanks go to Anne Legendre for statistical assistance and to Mee-Lan Frank and Maartje Michelson for editorial support. The views expressed here are the authors' personal views, and do not necessarily reflect those of the OECD or its member countries. 
Table 1. Selected infrastructure indicators

Water and sanitation

Improved sanitation facilities (\% of population with access)

Improved water source (\% of population with access)

\section{Energy and transport}

Electric power consumption (kWh per capita)

Electric power transmission and distribution losses

(\% of output)

Roads, paved (\% of total roads)

Information and communication technologies

Fixed broadband subscribers (per 100 people)

Internet users (per 100 people)

Telephone lines (per 100 people)

Mobile cellular subscriptions (per 100 people)

\begin{tabular}{|c|c|c|c|c|c|}
\hline \multicolumn{3}{|c|}{ Brazil } & \multirow{2}{*}{$\begin{array}{l}\text { Chile } \\
2008^{2}\end{array}$} & \multirow{2}{*}{$\begin{array}{c}\begin{array}{c}\text { South } \\
\text { America }^{1}\end{array} \\
2008^{2}\end{array}$} & \multirow{2}{*}{$\begin{array}{c}\text { OECD } \\
2008^{2}\end{array}$} \\
\hline 1995 & 2000 & $2008^{2}$ & & & \\
\hline 72 & 75 & 80 & 96 & 83 & 97.5 \\
\hline 91 & 93 & 97 & 96 & 92.2 & 99.0 \\
\hline 1637.7 & 1893.6 & 2170.7 & 3318.2 & 2020.8 & 8417.1 \\
\hline 16.7 & 18.2 & 16.1 & 8.4 & 15.1 & 6.3 \\
\hline 8.9 & 10.5 & 13.8 & - & - & 84.9 \\
\hline & 0.06 & 5.26 & 8.49 & 5.25 & 21.8 \\
\hline 0.1 & 2.9 & 37.5 & 32.5 & 29.1 & 63.2 \\
\hline 8.2 & 17.8 & 21.4 & 21.0 & 18.9 & 42.8 \\
\hline 0.8 & 13.3 & 78.4 & 88.1 & 95.3 & 99.9 \\
\hline
\end{tabular}

1. Unweighted average of Argentina, Chile, Colombia, Paraguay, Peru, Uruguay and Venezuela.

2. 2008 or latest available year.

Source: World Bank (World Development Indicators).

The situation varies widely across states and municipalities. In general, access to infrastructure services is more widespread in high-income regions. This is the case for services where local authorities are responsible for provision, such as sewerage (Figure 1), but also in sectors where the federal government has been a major investor, like road transport. Nevertheless, there is evidence that regional disparities in access to sanitation services narrowed somewhat from 2002 to 2008 . Some disparities also remain in the telecommunication sector and between rural and urban areas. Access to fixed lines is higher in the South-East region than in the North and North-East regions. The number of connections to fixed telephone lines and cable TV in metropolitan areas appears to be at least double of that in rural areas.

\section{Figure 1. Percentage of sewage collected by states grouped by regions}

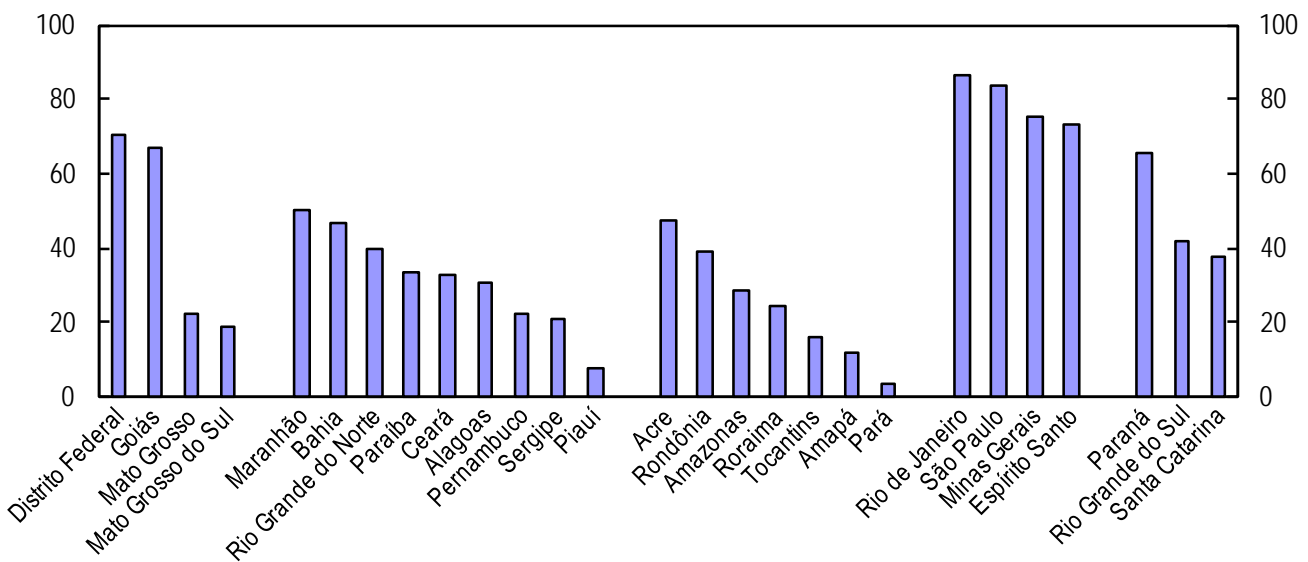

Source: Ministry of Cities, Sistema national de informações sobre saneamento - SNIS. 
Infrastructure quality, which is usually well correlated with quantity indicators, varies across sectors (Calderón and Servén, 2010). The situation is particularly critical for water and sanitation. The quantity of chlorine residual was on average 63\% higher than the minimum required after sewage treatment in 2008. Water distribution losses were on average around 29\% of production in 2008, but some firms reported figures of up to $75 \%$. Quality appears to be better in the electricity sector, where losses in distribution and transmission amounted to 9\% of domestic energy supply in 2009. Overall, Brazil ranked $62^{\text {nd }}$ out of 139 countries for the quality of its infrastructure in the 2009-10 World Economic Forum survey.

\section{Financing of infrastructure projects}

\section{Public infrastructure spending before the mid-2000s}

The relatively poor state of infrastructure reflects underspending over at least three decades. Public infrastructure spending has been growing at an increasing though moderate pace since the turn of the millennium to reach $2.1 \%$ of GDP in 2009. This increase is attributable to the transport and, to a lesser extent, the water and sanitation sectors (Figure 2). A number of factors contributed to this slow growth. First, infrastructure-dedicated federal taxes - earmarked for energy, transport, telecommunications and electricity - were abolished in the 1988 Constitution without identifying new funding alternatives (Afonso et al., 2005; World Bank, 2007). The share of the unemployment benefit fund (FAT) transferred to BNDES is now the only revenue stream partly earmarked for infrastructure projects. ${ }^{2}$ At the same time, the Constitution has introduced widespread revenue earmarking favouring current spending, especially in health and education, at the expense of capital and infrastructure outlays, which are therefore left to the discretion of policymakers (Figure 3).

Figure 2. Public spending on infrastructure by sector and government

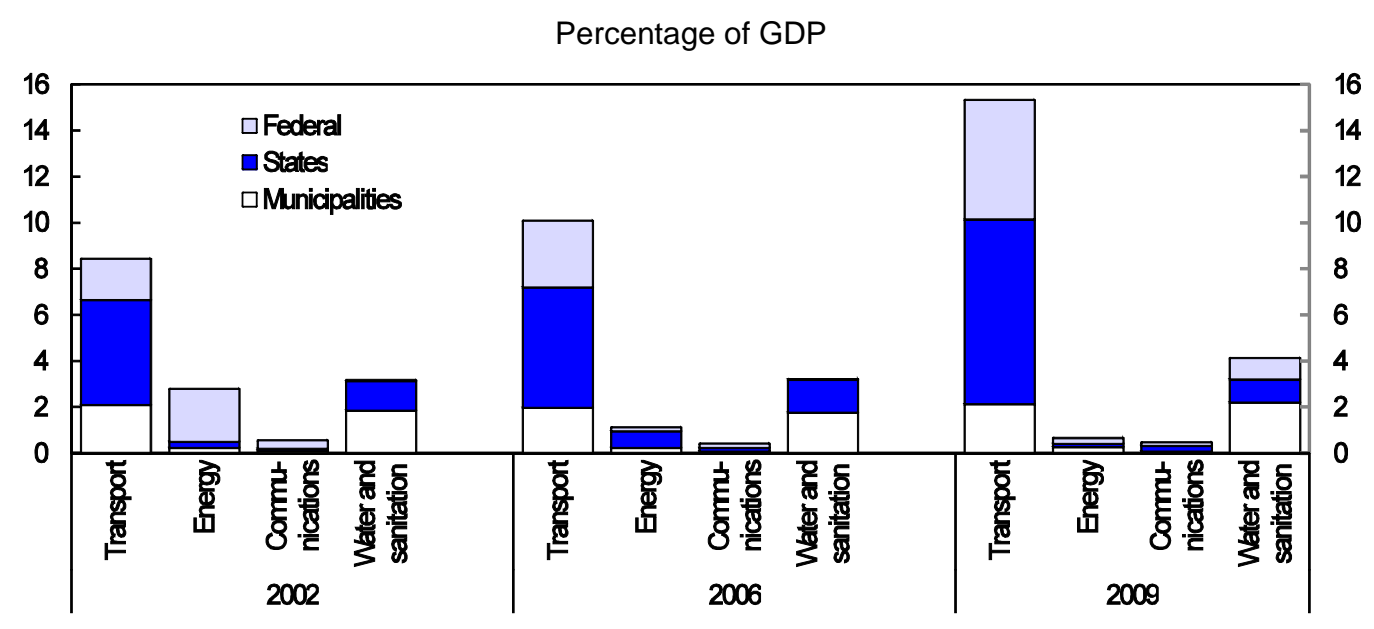

Source: Ministry of Finance.

2. There was an attempt to increase earmarking for the infrastructure sector in 2001 with the establishment of a federal tax (Contribução sobre Intervençao no Domínio Econômico,CIDE-combustiveis) to finance investment and maintenance in the transport sector, but between 2002 and 2004 only a limited share of the revenues of CIDE-combustiveis (14\%) was allocated to road transport (Afonso et al., 2005). 


\section{Figure 3. Social and education versus infrastructure spending}

Percentage of general government spending ${ }^{1}$

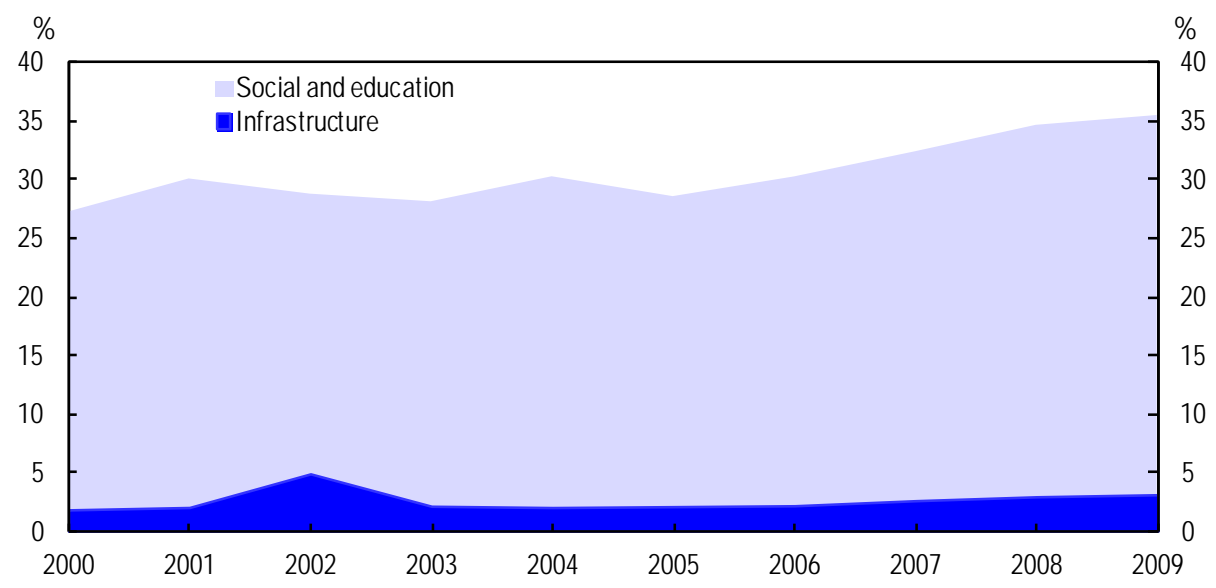

1. Social spending includes health and social insurance.

Source: Ministry of Finance.

Figure 4. Primary surplus and public infrastructure investment

Per cent of GDP

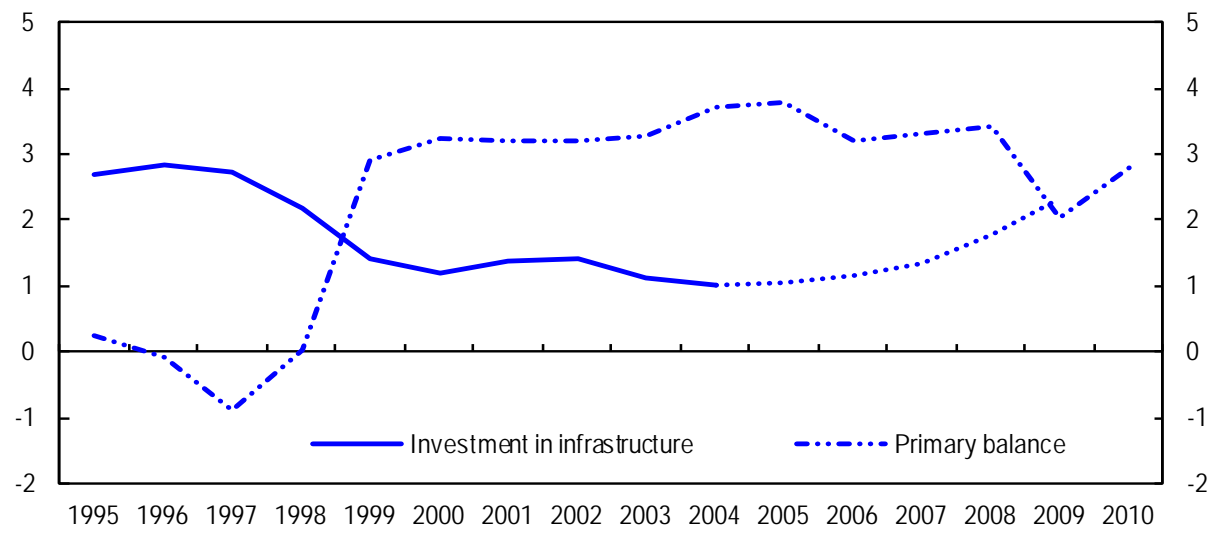

Note: Sectors covered include transport, sanitation, communications and electricity. Given the lack of official data, total government investment in infrastructure has been extrapolated using data on federal investment in infrastructure after 2005.

Source: Afonso et al. (2005), IPEA (2010a) and OECD calculations.

Second, the general trend towards devolving infrastructure spending decisions to municipalities and states has probably exacerbated the problem of low infrastructure spending in some sectors (Afonso et al., 2005). While federal transfers to sub-national governments have increased since 2002, and federal resources available for capital spending in infrastructure investment were reduced from 2002 to the mid-2000s, particularly in communications and energy. But this was not compensated by a pick up in sub-national governments' infrastructure spending, probably because they had neither the resources nor the expertise in planning and delivering infrastructure policies and projects. At the same time, private investment expansion was insufficient to offset the fall in public investment. As a result, investment in infrastructure had been declining since the late 1990s (Figure 4). The drop affected all sectors (Ferreira and 
Araujo, 2010). Evidence from IPEA (2010a) suggests that the stock of public infrastructure started to rise after 2007.

\section{Growth Acceleration Programme infrastructure programmes}

Against this background, the government launched a large infrastructure programme in 2007, the Growth Acceleration Programme (Programa de aceleração do crescimento, PAC), followed in 2010 by a follow-up programme. These programmes replaced the Investment Pilot Project (Projeto Piloto de Investisment, PPI) announced in 2005. The aim was to increase both private and public infrastructure investment and improve co-ordination among the several bodies involved in infrastructure policy (Box 1). This resulted in a marked increase in the GDP share of public investment to an estimated $3.2 \%$ in 2010, with more than $60 \%$ of this investment coming from state-owned enterprises. Overall, the first stage of the programme was successful. However, projects' delivery and spending execution were initially held back by a lack of capacity in project planning and management, difficulties in obtaining environmental licences and, in a few cases, procedural irregularities (IPEA, 2010). It took approximately two years for infrastructure spending to take off, and only about 82\% of the planned 2007-10 projects were completed. But PAC also fostered the building up of expertise and capacity at the central and local levels. Looking forward, most of the factors that led to execution delays are expected to diminish, licences being an exception (see below). In June 2011, the government proposed a bill to speed up projects by holding a single tender for both public works' design and construction of urban transportation, airport and stadiums projects related to the World Cup, as delays were still important in these areas. Efforts have also been made to enhance integrity and lower corruption risks related to these events (OECD, 2010).

Current investment plans are estimated to increase to BRL 757 billion over the next four years, representing around 5.1\% of 2010 GDP per year (Table 2). The bulk of total projected investments are expected to occur in the oil and gas and electricity sectors. For sectors where information is available, investments appear to be in general higher than what was initially planned in the second phase of PAC.

Table 2. Investment plans

\begin{tabular}{lc|c|c|c}
\hline \multirow{2}{*}{\multicolumn{1}{c}{ Sectors }} & 2006-09 & \multicolumn{3}{c}{ 2011-14 } \\
\cline { 2 - 5 } & BRL billions & BRL billions & $\begin{array}{c}\text { Per cent of } \\
\text { 2010 GDP }\end{array}$ & Share \\
\hline Electricity & & & & \\
Telecommunications & 92 & 139 & 1.0 & 18.4 \\
Sanitation & 62 & 70 & 0.5 & 9.3 \\
Railways & 26 & 41 & 0.3 & 5.4 \\
Highways & 20 & 60 & 0.4 & 7.9 \\
Ports & 30 & 51 & 0.4 & 6.7 \\
Oil and gas & 5 & 18 & 0.1 & 2.4 \\
\hline
\end{tabular}

Source: BNDES (2011).

In addition to extending the infrastructure network, PAC seeks to improve the quality of the existing stock by raising public resources allocated to operation and maintenance (O\&M). O\&M have already been separated from other expenses in railways, and a similar separation is planned in others. In addition, O\&M costs are used as a criterion in PAC project selection. These are laudable initiatives, but O\&M spending is still likely to be hindered by the lack of precise spending guidelines. For this reason, the authorities should focus on setting specific rules to quantify the yearly O\&M costs of existing and planned infrastructure and incorporate them in multi-year budgets so as ensure adequate financial cover. This will also lead to better estimates of the total costs of infrastructure projects. In addition, identifying a stable source of funding for maintenance and rehabilitation would be beneficial. 
While the PPI programme had initially focused on the most growth-enhancing projects, the coverage of the PAC programme has been expanded over time. It now includes a very wide range of projects, covering several aspects of infrastructure, including both social housing and investment in oil and gas, and involves many actors. Such a broad coverage is based on a structuralist approach à la Rosenstein-Rodan whereby the state should undertake public investment and promote and co-ordinate private investments. According to this view, the expansion of production in one sector is profitable only if it is accompanied by the expansion of production in other sectors. However, the various federal ministries engaged in infrastructure investment have not been able to co-ordinate policies satisfactorily, leading sometimes to inconsistent developments at the economy-wide level. To address this issue, the government has increased resources to monitor progress in the infrastructure programmes and publishes a progress report four times a year. The PAC Secretariat also helps to set targets for individual projects within PAC. In addition, the government concentrates on the large and strategically important infrastructure projects in its PAC reports. It would be useful to give priority on completing the most worthwhile projects within PAC.

At the beginning of 2011, the management and the implementation of PAC was moved to the Ministry of Planning, which is in charge of co-ordination and budgeting. If co-ordination remains an issue, the authorities could consider setting up a dedicated agency to oversee infrastructure developments. Such an agency would assess projects on a common basis and co-ordinates infrastructure policies by advising central and local governments on priorities and possible financing mechanisms. For its first task, the Brazilian agency could be asked to assess infrastructure needs and the impact of PAC projects on economic growth and public finances at the economy-wide level. This would complement current partial information, which is often restricted to sectoral developments alone.

The budgetary cost of the second stage of PAC will obviously depend on the share of investments financed by the private sector, as well as the estimated effect of infrastructure on economic growth (Figure 5). In the first stage of the programme private investment represented about $30 \%$ of total investment, and this share is expected to be slightly reduced for the follow-up programme. Using this share and an admittedly high elasticity from Ferreira and Araujo (2010), together with a tax elasticity estimated by de Mello and Moccero (2006), PAC is found to be more than self-financed in the long term. However, a similar exercise, using more conservative elasticities of around half the value estimated by Ferreira and Araujo (2010), suggests that the financing of PAC could enlarge the deficit by around 1.7 percentage points of GDP, on the assumption that $30 \%$ of the cost is privately financed. The share of private financing would need to amount to $80 \%$ to have a neutral effect on public finances. A $80 \%$ target appears to be very ambitious given the current business environment (Arnold, 2011). This suggests that fiscal room will have to be created to finance PAC measures or private participation will have to play a much more important role than in the past and than what is currently envisaged.

\section{Box 1. The Growth Acceleration Programme}

The Growth Acceleration Programme (Programa de aceleração do crescimento, PAC) sought to raise economic growth and enhance social inclusion through increasing public and private spending in key infrastructure sectors defined in a very broad sense, i.e. including transport, energy but also urban development. PAC is managed by the Comitê Gestor do PAC (CGPAC), comprised of the ministers of Casa Civil (Presidency), Planning and Finance. An executive group (the Grupo Executivo do PAC, GEPAC) is responsible for PAC's implementation and a Secretariat (Secretaria do Programa de aceleração do Crescimento) helps to set targets in PAC projects.

PAC does not aim solely at launching and delivering new projects but also at renovating and renewing the already existing infrastructure stock. The programme also grants tax exemptions to infrastructure projects through a special regime that encourages infrastructure developments (Regime Especial de Incentivos para o Desenvolvimento da Infraestrutura, REIDI). This complements other fiscal incentives provided by states using for instance the VAT tax. Given its magnitude and scope, the government sees Public Private Partnerships as an important element to achieve PAC's targets. Project selection is undertaken at the federal level in consultation with states and municipalities. 


\section{Box 1. The Growth Acceleration Programme (cont'd)}

Total spending during the first phase of the programme, from 2007 to 2010 , amounted to BRL 503.9 billion (4.7\% of 2007 GDP on average per year), of which around 55\% was devoted to energy, $12 \%$ to logistics and the remainder to urban and social development programmes. With regards to its geographical distribution, around 36\% of PAC's planned expenditure was allocated to cross-state projects. The South-East region received the largest share of spending, about $26 \%$, mainly attributable to energy and urban and social development projects, and the Centre-West the lowest, less than 5\%. While massive, PAC investments appear to have been much lower than the country's needs. IPEA (2010a) shows, for instance, that needs for highways amounted for about BRL 170 billion as opposed to BRL 23 billion invested by PAC. The largest gaps were reported for the North-East region.

The second phase of the programme was launched in early 2010. The total planned spending is around 50\% larger than that of the first phase (Table 3). Resources for urban and social infrastructure were hiked considerably because of the large housing project (Minha Casa, Minha Vida) aiming at building 2 million new dwellings by 2014 , $60 \%$ of which for low-income families. Excluding oil and gas and housing, planned spending is estimated to reach BRL 394.9 billion over the next four years, representing an average of around $2.7 \%$ of 2010 GDP per year.

\section{Table 3. PAC planned spending}

BRL billions

\begin{tabular}{lrr}
\hline & $2011-14$ & After 2014 \\
\cline { 2 - 3 } & & \\
Transport & 104.5 & 4.5 \\
Roads & 50.2 & 2 \\
Railways & 43.9 & 2.1 \\
Ports and water transport & 7.4 & 0.4 \\
Airports & 3.0 & 626.9 \\
Energy & 461.6 & 33.7 \\
Electricity (generation and distribution) & 140.3 & 593.2 \\
Oil and gas & 281.9 & \\
Other & 39.4 & \\
Urban development & 57.1 & \\
Sanitation & 22.1 & \\
Urban transport & 18.0 & \\
Urban roads & 6.0 & \\
Other & \\
Urban social development & 11.0 & \\
Housing (Minha Casa, Minha Vida) & 23.0 & \\
Water and light (Agua and Luz para Todos) & 278.2 & \\
Light & 30.6 & \\
Water in urban areas & 5.5 & \\
Water resources & 13.0 & \\
Total & 12.1 & \\
\hline
\end{tabular}

1. Includes industrial shipping, renewable energy, energy efficiency and mineral exploration.

2. Includes control and prevention of floods, landslides and coastal erosion.

Source: http://www.brasil.gov.br/pac. 
Figure 5. Long-term effect of the PAC programme on the public deficit

Per cent of GDP

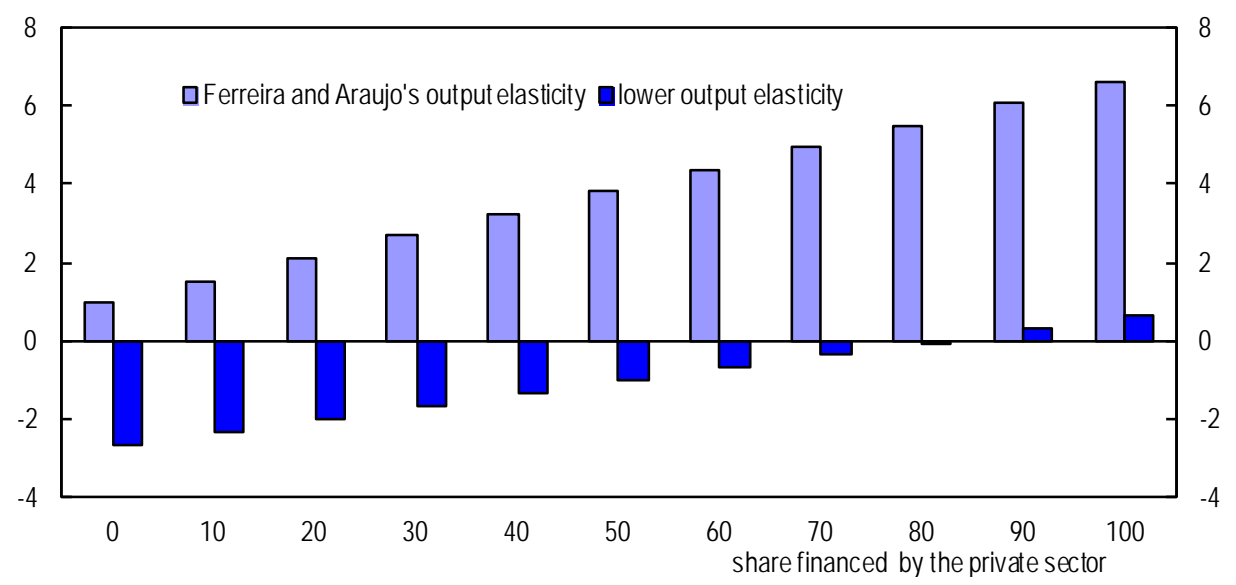

Source: OECD calculations using Ferreira and Araujo (2010) and de Mello and Moccero (2006).

\section{Private participation}

Brazil has started to attract private capital into infrastructure provision earlier than other Latin American countries apart from Chile. Initially, private participation was concentrated in the telecommunication sector. Since 2004, a surge in private projects has been observed in the energy sector and since 2006 in the transport sector (Figure 6). Private investment in infrastructure as a per cent of GDP appears to be higher in Brazil than in regional peers, even though it has declined (Figure 7).

Figure 6. Total investment in private projects by sector

USD billions, annual average over the period

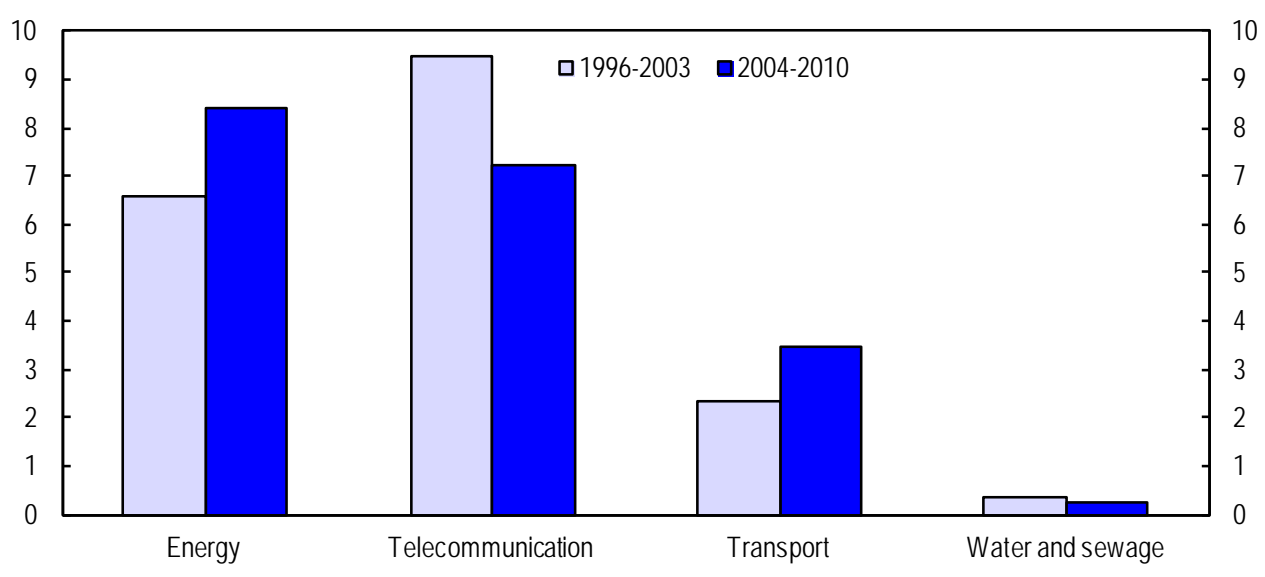

Source: World Bank and PPIAF, PPI Project Database. 
Figure 7. Total investment in private projects in energy, telecommunications and transport in South America

Per cent of GDP

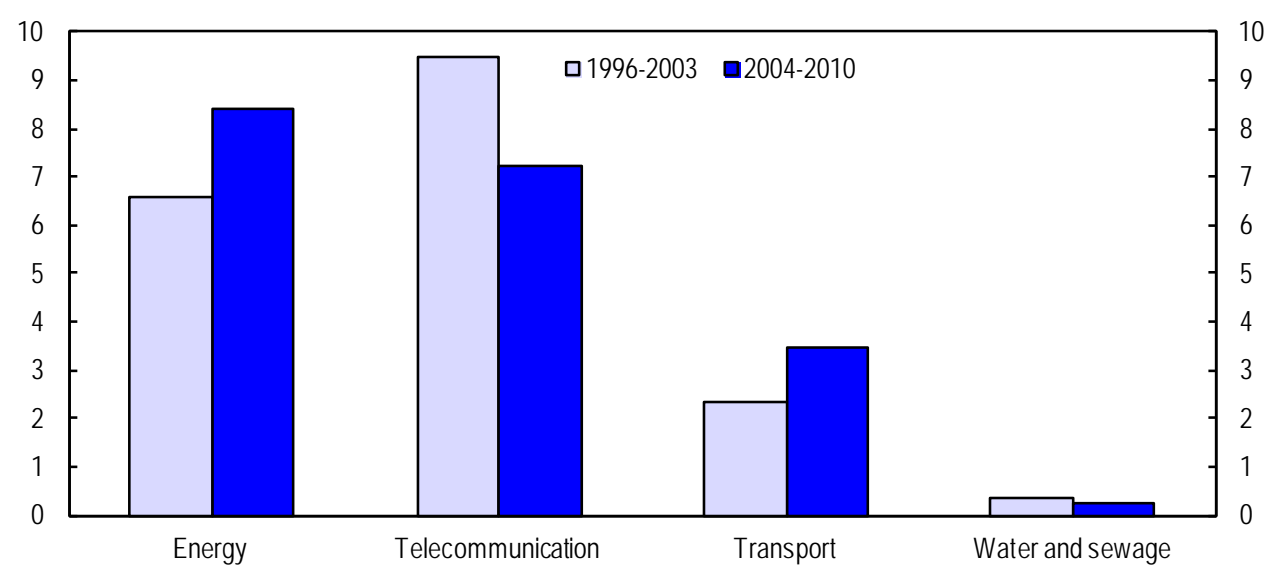

Source: World Bank and PPIAF, PPI Project Database.

The country has extensive experience with concession contracts, especially at sub-national levels. The general framework for franchise and concession appears to be open and transparent, with features similar to those observed in the majority of OECD countries. At the end of the franchise period, contracts are usually renewed in all sectors but water. Exclusivity clauses can be inserted in Brazil but not clauses enforcing the re-investment of profits, as is the case in many OECD countries. In addition, contracts specify minimum quality standards, which can be translated into measureable output indicators. This is more demanding than what can be found in most OECD countries. As in some OECD countries, performance is not assessed against competitive benchmarks, but bonuses and penalties are specified in contracts in most sectors.

In 2004, a law introduced a distinction between Public Private Partnerships (PPPs) and concessions. Concessions are awarded for those projects that are financially viable without any payment to the private operator by public authorities (i.e. they rely on user charges alone). Projects requiring a direct payment from public authorities to the private partner to be financial viable are classified as PPPs. The law contains provisions regulating several aspects of PPPs such as project selection, bidding, signing and management of projects at all levels of government, including companies and agencies under the control of the public sector. It also ensures PPP-related government obligations are incorporated in the budget and sets a ceiling on obligations arising from PPPs for all the three government levels. Overall, this law is likely to limit the occurrence of costly renegotiations, which have frequently impaired PPP contracts in the past in Latin America (Calderón and Servén, 2010). It also enhances the transparency of the whole process. In addition, the relatively sound regulatory framework in most sectors offers a favourable environment to gain from private participation in infrastructure.

Overall, despite some positive aspects, the new legal framework for PPPs has failed to generate the expected increase in the number of PPP projects (the federal government has yet to sign its first contract). ${ }^{3}$ This is partly attributable to the careful attitude of the authorities to project selection. The government's announcement that it intends to make more use PPPs, in particular in the road sector, is a step in the right direction. Improving the business environment is the first option to attract further private investment in

3. Since the 2004 law only two PPPs have been signed in the road sector, by the state governments of Minas Gerais and of Pernambuco (ABCR, 2010). 
infrastructure sectors. Égert et al. (2009) show that actions aiming at enhancing competition in infrastructure sectors, allowing for cost-recovery tariffs and imposing hard budget constraints on public utilities all help to boost private investment.

As changes to the business environment may take time to materialise, the infrastructure authorities should consider simplifying the current management process of PPPs and concessions. Numerous agencies at federal, state and municipal levels are involved in managing PPPs and concession contracts and shaping the regulatory framework. The Court of Audit (Auditor General) exerts a general control on different stages of PPPs and the fiscal accounting of signed contracts. BNDES, the national development bank, has responsibility during the development stage for advising the federal government, states and municipalities on how to best structure PPP projects. Following the 2004 law, a committee and a fund were created to guarantee and manage PPPs and related obligations. Progresses have been made on circulating instructions on procedures, and further improvements are likely to be achieved as the different actors involved become accustomed to the process. Still, responsibilities among the numerous authorities concerned could be consolidated to streamline the process of project selection and evaluation. The existence of standardised contracts could also overcome some of the important transactions costs associated with PPPs.

\section{The regulatory framework}

A sound regulatory framework is key to the development of infrastructure, by lowering regulatory uncertainty usually associated with large and long lived investment projects. In particular, the presence of independent sectoral regulators, appropriate price regulations, calls for tender and FDI restrictions are important features of a best-practise framework and are discussed in turn in this section. The analysis relies extensively on information collected through an Infrastructure Investment Questionnaire sent to OECD national authorities in winter 2008 (Égert et al., 2009). The same questionnaire was sent to the Brazilian authorities in autumn 2010. The information contained in the responses needs to be interpreted with caution, as with OECD Member countries. While it is likely to capture the de jure regulatory framework, it says little as regards the de facto situation.

\section{Sectoral regulators}

Regulatory agencies were created after 1996 and were inspired by the North American institutional model of independent regulatory agencies (Pires and Goldstein, 2001). As in most OECD countries, there is in general a single federal regulator per sector in Brazil, except for gas distribution in which regulatory bodies operate at the state level. All federal regulatory agencies are under the regime of "autarquia especial”, meaning that they are independent but administratively linked to a line ministry. In particular, regulatory authorities are granted a degree of independence in Brazil similar to many other OECD countries in most sectors (Table 4). In addition to federal regulators, state-level governments also have regulatory agencies, which can be either multi-sector or sector-specific institutions.

A growing body of evidence suggests that having independent regulators results in better industry performance and may help to foster private investment (Égert et al., 2009). Institutions in Brazil have been strengthened over the past eight years, with progress made in recruitment, public procurement and pay policies within the federal government. Still, sectors appear to be at different states of development, and the lack of a complete framework sometimes makes some federal regulatory agencies vulnerable to policy capture in areas such as transport and water and sanitation (Correa et al., 2006; Seroa da Motta and Moreira, 2006). In addition, state regulatory agencies are found to be less autonomous than their federal counterparts, particularly in transport, sewerage, gas and electricity. Moreover, in all sectors but energy, the regulatory authority receives instruction from the executive, contrary to what is observed in many OECD countries, signalling that they may not enjoy full independence. 
Table 4. Independence of the regulatory authority

\begin{tabular}{|c|c|c|c|c|c|c|}
\hline & \multicolumn{2}{|c|}{$\begin{array}{l}\text { The regulatory authority } \\
\text { is independent from the } \\
\text { executive and has its own } \\
\text { legal status and budget }\end{array}$} & \multicolumn{2}{|c|}{$\begin{array}{l}\text { Does the regulatory } \\
\text { authority receive instructions } \\
\text { from the executive? }\end{array}$} & \multicolumn{2}{|c|}{$\begin{array}{l}\text { Can the executive } \\
\text { overturn the decisions o } \\
\text { the regulatory authority? }\end{array}$} \\
\hline & Brazil & $\mathrm{OECD}^{1}$ & Brazil & $\mathrm{OECD}^{1}$ & Brazil & $\mathrm{OECD}^{1}$ \\
\hline Electricity & Yes & $73 \%$ & No & $27 \%$ & No & $23 \%$ \\
\hline Gas & Yes & $73 \%$ & No & $30 \%$ & No & $20 \%$ \\
\hline Telecommunications & Yes & $83 \%$ & Yes & $10 \%$ & No & $17 \%$ \\
\hline Railways & Yes & $53 \%$ & Yes & $43 \%$ & No & $30 \%$ \\
\hline $\begin{array}{l}\text { Operation of road infrastructure } \\
\text { Operation of air transport infrastructure }\end{array}$ & $\begin{array}{l}\text { Yes } \\
\text { Yes }\end{array}$ & $\begin{array}{l}29 \% \\
39 \%\end{array}$ & $\begin{array}{l}\text { Yes } \\
\text { Yes }\end{array}$ & $\begin{array}{l}44 \% \\
48 \%\end{array}$ & $\begin{array}{l}\text { No } \\
\text { No }\end{array}$ & $\begin{array}{l}44 \% \\
44 \%\end{array}$ \\
\hline $\begin{array}{l}\text { Operation of water transport } \\
\text { infrastructure }\end{array}$ & Yes & $37 \%$ & Yes & $40 \%$ & No & $36 \%$ \\
\hline
\end{tabular}

1. Percentage of 25 OECD countries that replied positively to the question.

Source: OECD Infrastructure Questionnaire and PMR questionnaire.

Recently, the authorities have envisaged reducing the scope of competency of the electricity regulatory agency (ANEEL) and giving the Chamber of Commerce the authority to suspend a contract or even shut down a market player, without the involvement of the regulatory agency. At the same time, the intent is to reform the structure of the Chamber of Commerce and allow the federal government to appoint two members of its executive board. It is important to preserve the independence of the regulator from the government and the industry. The proposed changes may increase the risk of capture by the industry and should be resisted.

As in most OECD countries, regulatory authorities are responsible for implementing regulations and verifying compliance (Table 5). They also have some powers in applying fines and sanctions and designing specific rules, but these powers are generally shared with the executive, parliament or the competition authorities. Regulatory independence is counterbalanced by the possibility of making appeals in court against regulators' decisions, as is the case in many OECD countries, but also by the existence of an arbitration procedure in most sectors. This feature is observed in only a minority of OECD countries.

\section{Price regulation}

Prices are regulated in all network industries except gas production in Brazil. This is a common feature in OECD countries and can be justified by the existence of natural monopoly, the presence of positive externalities, and the high political and social sensitivity of some sectors. Regulating prices is also a necessity when the core monopoly network provider must ensure access to it for different service operators under payment of an access fee - as in the electricity transmission network - or when markets can only be periodically contested - as in concessions for toll roads or water supply.

The optimal price regulation regime depends on industry characteristics. Pure price cap is the most common form of price regulation and can be found in electricity, road infrastructure and fixed line services and in some areas in gas transmission. This type of regulation simulates competition, offers strong incentives to adopt cost-saving technology and increase efficiency, but it has also been found to lead more often than cost-based pricing to contract renegotiation (Guasch et al., 2003 and 2007). Price caps, if associated with independent regulators, have been found to boost infrastructure investment in OECD countries (Égert, 2009). Cost-based regulation prevails in water and air transport sectors, as was found to be the case in the majority of OECD countries that responded to the questionnaire. 
ECO/WKP(2011)67

Table 5. Powers of regulatory authorities in infrastructure industries

\begin{tabular}{|c|c|c|c|c|c|c|}
\hline & \multicolumn{2}{|c|}{$\begin{array}{l}\text { Design specific rules for } \\
\text { the sector }\end{array}$} & \multicolumn{2}{|c|}{$\begin{array}{l}\text { Implement regulations and } \\
\text { verify compliance }\end{array}$} & \multicolumn{2}{|c|}{$\begin{array}{c}\text { Power to apply fines and } \\
\text { sanctions }\end{array}$} \\
\hline & Brazil & $\mathrm{OECD}^{1}$ & Brazil & $\mathrm{OECD}^{1}$ & Brazil & $\mathrm{OECD}^{1}$ \\
\hline $\begin{array}{l}\text { Electricity, consisting of: } \\
\text { electricity generation } \\
\text { electricity transmission } \\
\text { electricity distribution and supply }\end{array}$ & $\begin{array}{l}\text { Yes, shared } \\
\text { Yes, shared } \\
\text { Yes, shared }\end{array}$ & $\begin{array}{l}64 \% \\
84 \% \\
88 \%\end{array}$ & $\begin{array}{l}\text { Yes } \\
\text { Yes } \\
\text { Yes }\end{array}$ & $\begin{array}{l}68 \% \\
92 \% \\
92 \%\end{array}$ & $\begin{array}{l}\text { Yes, shared } \\
\text { Yes, shared } \\
\text { Yes, shared }\end{array}$ & $\begin{array}{l}60 \% \\
76 \% \\
80 \%\end{array}$ \\
\hline $\begin{array}{l}\text { Gas, consisting of: } \\
\text { gas production } \\
\text { gas transmission } \\
\text { gas distribution and supply }\end{array}$ & $\begin{array}{l}\text { Yes, shared } \\
\text { Yes, shared } \\
\text { Yes, shared }\end{array}$ & $\begin{array}{l}28 \% \\
84 \% \\
88 \%\end{array}$ & $\begin{array}{c}\text { Yes } \\
\text { Yes } \\
\text { Yes, shared }\end{array}$ & $\begin{array}{l}36 \% \\
92 \% \\
92 \%\end{array}$ & $\begin{array}{l}\text { Yes, shared } \\
\text { Yes, shared } \\
\text { Yes, shared }\end{array}$ & $\begin{array}{l}28 \% \\
76 \% \\
76 \%\end{array}$ \\
\hline Water collection, purification and distribution & Yes, shared & $40 \%$ & Yes & $44 \%$ & Yes, shared & $36 \%$ \\
\hline $\begin{array}{l}\text { Railway transportation } \\
\text { passenger transport } \\
\text { freight transport } \\
\text { operation of railroad infrastructure }\end{array}$ & $\begin{array}{l}\text { Yes, shared } \\
\text { Yes, shared } \\
\text { Yes, shared }\end{array}$ & $\begin{array}{l}40 \% \\
40 \% \\
36 \%\end{array}$ & $\begin{array}{l}\text { Yes } \\
\text { Yes } \\
\text { Yes }\end{array}$ & $\begin{array}{l}52 \% \\
48 \% \\
56 \%\end{array}$ & $\begin{array}{l}\text { Yes, shared } \\
\text { Yes, shared } \\
\text { Yes, shared }\end{array}$ & $\begin{array}{l}52 \% \\
52 \% \\
56 \%\end{array}$ \\
\hline Operation of road infrastructure & Yes, shared & $44 \%$ & Yes & $44 \%$ & Yes, shared & $44 \%$ \\
\hline Operation of water transport infrastructure & Yes, shared & $44 \%$ & Yes & $48 \%$ & Yes, shared & $40 \%$ \\
\hline $\begin{array}{l}\text { Air transportation, consisting of: } \\
\text { air transport } \\
\text { operation of air transport infrastructure }\end{array}$ & $\begin{array}{l}\text { Yes, shared } \\
\text { Yes, shared }\end{array}$ & $\begin{array}{l}44 \% \\
48 \%\end{array}$ & $\begin{array}{l}\text { Yes } \\
\text { Yes }\end{array}$ & $\begin{array}{l}48 \% \\
48 \%\end{array}$ & $\begin{array}{l}\text { Yes, shared } \\
\text { Yes, shared }\end{array}$ & $\begin{array}{l}60 \% \\
64 \%\end{array}$ \\
\hline $\begin{array}{l}\text { Telecommunications, consisting of: } \\
\text { fixed-line network } \\
\text { fixed-line service } \\
\text { mobile services } \\
\text { internet services }\end{array}$ & $\begin{array}{l}\text { Yes, shared } \\
\text { Yes, shared } \\
\text { Yes, shared } \\
\text { Yes, shared }\end{array}$ & $\begin{array}{l}80 \% \\
80 \% \\
80 \% \\
76 \%\end{array}$ & $\begin{array}{l}\text { Yes } \\
\text { Yes } \\
\text { Yes } \\
\text { Yes }\end{array}$ & $\begin{array}{l}96 \% \\
96 \% \\
96 \% \\
88 \%\end{array}$ & $\begin{array}{l}\text { Yes, shared } \\
\text { Yes, shared } \\
\text { Yes, shared } \\
\text { Yes, shared }\end{array}$ & $\begin{array}{l}84 \% \\
84 \% \\
84 \% \\
80 \%\end{array}$ \\
\hline
\end{tabular}

1. Percentage of $25 \mathrm{OECD}$ countries that replied positively to the question and whose regulatory authorities are responsible for the specific issue.

Source: OECD Infrastructure Questionnaire.

Investment needs are usually the main criteria taken into account when the regulator determines the prices firms are allowed to charge (Table 6). Prices are differentiated according to the type of customer and to a lesser extent the distance between production and customers. Demand has an impact on prices only in water, transport, road and mobile telecommunication services sectors. In line with most OECD countries, prices in most sectors are adjusted during the next round of contract revision in case of cost-saving investment.

\section{Environmental licensing}

Environmental licences appear to be a source of investment delay, particularly in the energy sector, the main issue being the resolution of disputes rather than meeting environmental requirements per se. Licences cannot be obtained in Brazil before calls for tender are made (Table 7). Some large plants especially large hydro facilities - had to wait for an environmental green light for over a decade (OECD, 2008). On average environmental licensing costs have been estimated at 15 to $20 \%$ of the total cost of the project, of which only $2 \%$ is related to environment requirements, while $80 \%$ is attributable to the cost of relocating population, and supporting communities and municipalities in several social areas (World Bank, 2008). Some of these costs are inherent to the projects and would have occurred even in the absence of the licensing process. In the past one reason for delays was the lack of adequate staffing in planning functions at the government level in the aftermath of the fiscal consolidation plans. To address this, the government established the Energy Research Company (EPE, Empresa de Pesquisa Energética) in 2004 to plan and design projects in the energy sector and support the national energy policy. This has improved the government planning capacity and sped up the delivery of licences. 
Table 6. Degree of price regulation in infrastructure industries

\begin{tabular}{|c|c|c|c|c|}
\hline & \multicolumn{4}{|c|}{ Are prices regulated? } \\
\hline & \multirow{2}{*}{ Brazil } & \multicolumn{3}{|c|}{$\mathrm{OECD}^{1}$} \\
\hline & & Yes, for all prices & Partially & No \\
\hline $\begin{array}{l}\text { Electricity, consisting of: } \\
\text { electricity generation } \\
\text { electricity transmission } \\
\text { electricity distribution and supply }\end{array}$ & $\begin{array}{l}\text { Partially } \\
\text { Yes, for all prices } \\
\text { Yes, for all prices }\end{array}$ & $\begin{array}{l}0 \% \\
80 \% \\
28 \%\end{array}$ & $\begin{array}{l}20 \% \\
12 \% \\
68 \%\end{array}$ & $\begin{array}{l}64 \% \\
4 \% \\
4 \%\end{array}$ \\
\hline $\begin{array}{l}\text { Gas, consisting of: } \\
\text { gas production } \\
\text { gas transmission } \\
\text { gas distribution and supply }\end{array}$ & $\begin{array}{l}\text { No } \\
\text { Yes, for all prices } \\
\text { Yes, for all prices }\end{array}$ & $\begin{array}{l}0 \% \\
68 \% \\
36 \%\end{array}$ & $\begin{array}{l}8 \% \\
16 \% \\
56 \%\end{array}$ & $\begin{array}{c}48 \% \\
4 \% \\
4 \%\end{array}$ \\
\hline Water collection, purification and distribution & Yes, for all prices & $32 \%$ & $32 \%$ & $12 \%$ \\
\hline Operation of railroad infrastructure & Yes, for all prices & $32 \%$ & $32 \%$ & $12 \%$ \\
\hline Operation of road infrastructure & Yes, for all prices & $32 \%$ & $12 \%$ & $16 \%$ \\
\hline Operation of water transport infrastructure & Partially & $8 \%$ & $20 \%$ & $44 \%$ \\
\hline Operation of air transport infrastructure & Yes, for all prices & $8 \%$ & $52 \%$ & $16 \%$ \\
\hline $\begin{array}{l}\text { Telecommunications, consisting of: } \\
\text { fixed-line network } \\
\text { fixed-line service } \\
\text { mobile services }\end{array}$ & $\begin{array}{c}\text { Yes, for all prices } \\
\text { Yes, for all prices } \\
\text { Partially }\end{array}$ & $\begin{array}{l}12 \% \\
0 \% \\
0 \%\end{array}$ & $\begin{array}{l}68 \% \\
76 \% \\
64 \%\end{array}$ & $\begin{array}{l}16 \% \\
20 \% \\
20 \%\end{array}$ \\
\hline internet services & $\begin{array}{l}\text { Price was never } \\
\text { regulated }\end{array}$ & $0 \%$ & $24 \%$ & $40 \%$ \\
\hline
\end{tabular}

1. Percentage of 25 OECD countries that replied to the questionnaire. Percentages may sum to less than 100 because of non responses. Source: OECD Infrastructure Questionnaire.

Table 7. Investment planning

\begin{tabular}{|c|c|c|}
\hline & Brazil & OECD $^{1}$ \\
\hline $\begin{array}{l}\text { Does the contractor (a public body) usually obtain planning permission before calls for tender } \\
\text { are made? }\end{array}$ & Yes & $56 \%$ \\
\hline $\begin{array}{l}\text { As a principle, is environmental licensing obtained by the public body before calls for tender } \\
\text { are made? }\end{array}$ & No & $44 \%$ \\
\hline $\begin{array}{l}\text { If applicable, are local authorities' licenses obtained by the public body before calls for tender } \\
\text { are made? }\end{array}$ & No & $76 \%$ \\
\hline
\end{tabular}

1. Percentage of 25 OECD countries that replied positively to the questionnaire.

Source: OECD Infrastructure Questionnaire.

But frequent disputes still prolong the environment licensing process. Brazil is one of the very few countries that employ a three-stage process (Preliminary, Installation and Operating Licenses), with separate procedures for granting licenses at all three stages. This makes disputes more likely besides offering too many opportunities to restart or revisit old ones. Furthermore, it generates much uncertainty, lengthy delays and high transaction costs. In 2005, a timeline for each step was established, with the main objective of reducing the time spent during the first phase. Further progress could be achieved by the adoption of comprehensive rules for financial compensation for populations harmed by projects. In addition to increasing predictability, this would also hasten the process and lower the likelihood of disputes. 


\section{Developments in selected infrastructure sectors}

This section identifies the main challenges to promote infrastructure development in network industries. The focus is on electricity, telecommunications, road transport, railways and water and sanitation, all of which play important roles in Brazil's development strategy and account for an important share of PAC spending.

\section{Electricity}

Electricity generation in Brazil is dominated by hydropower, which represented about $80 \%$ of total generation in 2009 (Figure 8). Most of the electric energy is supplied by the regionally integrated grid transmission system (Sistema Interligado Nacional). In remote areas small diesel plants supply electricity but at high cost.

The state is still a major shareholder in the electricity sector. State ownership predominates in generation (80\% of assets). By contrast, over two-thirds of distribution assets are in private hands. The sector includes one very large government-controlled holding company, Eletrobrás, for generation, transmission and distribution, alongside a number of smaller companies. Petrobras, the state-owned oil company, owns over a fifth of thermal plant capacity.

The current model was introduced in 2004 in the aftermath of a major supply crisis in 2001. It replaced a framework that focused on privatisation and sought to move toward full competition, but failed to attract private investment because of inadequate pricing and institutional weaknesses with, in particular, a lack of strategic planning. The 2004 model aims at securing an adequate supply of power by attracting investment, exploiting potential hydro resources and promoting universal access via social programmes. A regulated market is organised around a wholesale power pool based on long-term contracts allocated through competitive auctions between generators and distribution companies. In addition, large consumers can deal directly with generating firms in a much smaller free market. Partial market opening and the managed framework of auctions are likely to mute price signals, which will not reflect short-term variations in demand.

The sector is mainly regulated at the federal level. The Ministry of Mines and Energy (MME) oversees the whole power sector and is responsible for policy setting. Created in 1996, the Electricity Regulatory Agency (ANEEL) is financed by a tax on power companies. The current legal framework appears to be a result of different reform waves since the mid-1990s. It consists of seven laws and related secondary legislation. Despite the lack of rationalisation, this framework is found to work efficiently (OECD, 2008).

The most important challenge lies in raising generation capacity to meet demand in the context of rapid economic development and increasing population. Official projections point to electricity consumption increasing by 5.0\% per year from 2010 to 2019 on average (Ministério de Minas e Energia and EPE, 2010). Meeting this demand will require important investment, in particular from the private sector, and improving the business environment will be a first step in this direction. 
Figure 8. Sources of electricity supply, 2009

Per cent of total supply

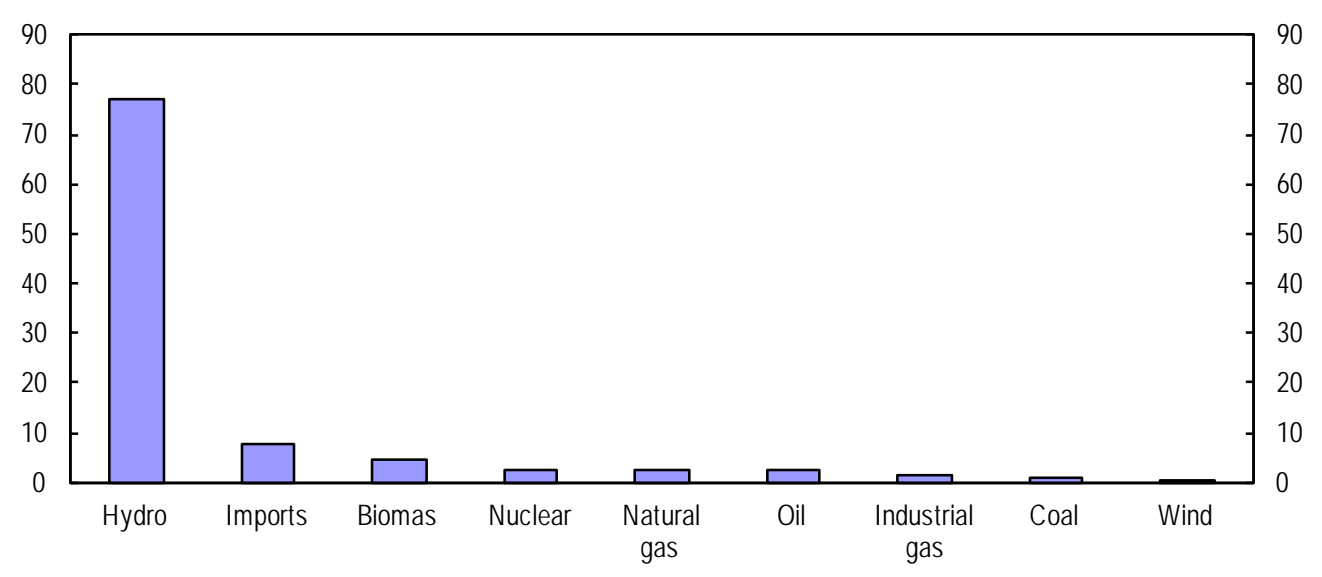

Source: Ministry of Mines and Energy.

Even though the 2004 model has managed to attract some investment in the electricity sector, the economy remains vulnerable to power shortfalls. A cushion is provided by imports of Bolivian natural gas to fuel thermal plants, although these may be vulnerable to political shocks. Looking forward, projections point to a substantial rise in domestic production of natural gas, but this is unlikely to fully address the problem. In this context, the government has sought to diversify generation sources through different options including new hydro plants or plants powered by other energy sources (thermal, nuclear, coal). In addition, the authorities are envisaging making prices more reactive to demand. One option currently being discussed is to create differentiated tariffs for low-voltage consumers by creating three differentiated tariffs throughout the day, depending on energy consumption. The idea is to encourage consumers to shift energy consumption to cheaper tariff periods to reduce the consumption peak. This proposal could diminish the risk of blackouts and is likely to be beneficial to the consumer. It should be implemented as soon as possible.

Cross-subsidisation can hinder the good functioning of electricity markets. This issue concerns not only the main incumbent, Eletrobrás, but also distribution companies, which sometimes belong to groups with interests in generation, although distribution firms are not allowed to own generation plants directly. "Regulatory accounts", which contain financial information related to individual firms (e.g. their subsidiaries) or activities have been demanded by the regulator on a regular basis to enforce effective separation in the absence of divestiture. It is not clear, however, to what extent these procedures are effective in preventing anti-competitive behaviour (OECD, 2008). In this context, an in-depth evaluation of the state of competition in the power sector is warranted and, if needed, should be followed up by actions to prevent cross-subsidisation, such as prohibiting distribution and generation firms from belonging to the same group. Given the dominant role played by Eletrobrás, it would be also useful to investigate whether there is room to open up generation to competition. Such cost-benefit analysis would be in line with best practice, as described in the 2001 Recommendations of the Council Concerning Structural Separation in Regulated Industries. Many OECD countries have moved toward structural separations in their electricity sectors, with particularly successful reforms in Australia and Chile (OECD, 2011).

Electricity tariffs vary across regions. This reflects differences in the size of concessions and population density, as well as in electricity sources. As a result extended geographical areas with low density are likely to experience much higher tariffs than smaller regions with large population. The first consequence is that incentives to invest in these regions may be lower, limiting access to high-quality 
electricity delivery in remote areas. In this context, the electrification programme Luz para Todos (LpT, Light for all) started in 2003 with the objective of bringing electricity to rural and remote areas by 2010 . The programme relied on substantial federal and state resources directed to service providers, who covered connection costs. The programme was successful, and universal access was almost reached in 2010. The second consequence is that tariffs may be prohibitively high for low-income households in some regions. In addition, tax (net of subsidies) accounted for about 35\% of the tariff in 2006, boosting prices. To address this issue, the authorities have implemented reduced social tariffs for low-income households. But these discounts can blur price signals and distort investment decisions. They can lead to cross-subsidisation across customers, with higher prices for high-volume customers and, in the case of firms, hampering their competitiveness. A more cost-effective way to support low-income households would be to make use of compensation programmes in the form of existing targeted cash transfer schemes, which, like the LpT, target the rural poor.

\section{Telecommunications}

The telecommunication sector has the most developed regulatory framework of all infrastructure industries in Brazil. Regulatory reforms started in the mid-1990s and revolved around the following principles: dismantling the state-owned company Telebrás; creating regional operators and introducing competition in the market; expanding the existing network to fulfil newly specified universal service obligations (USOs); and establishing a modern regulatory authority (Agencia National des Telecomunicações, ANATEL). The structure of the regulatory agency and its degree of independence are generally similar to those observed in a number of OECD countries (OECD, 2008).

However, the regulatory framework seems ill-suited to deal with the ongoing process of telecommunication and broadcasting service convergence. ANATEL focuses on telecommunications only, whereas broadcasting services are under the purview of the Ministry of Communications. The current legislative setting treats these two types of services as distinct and subject to different sets of rules and regulators. Yet, technological developments are leading to an rising overlap between them, with users increasingly exploiting them with the same tools/platforms. A number of OECD countries (for instance, the United Kingdom and Australia) have a single body responsible for regulating market entry in broadcasting (carriage) and cable operators, and the same body is also responsible for content regulation, access to spectrum and licensing (OECD, 2009). The Brazilian authorities should better co-ordinate the regulatory settings of the communication and broadcasting sectors to meet the reality of service convergence. Such a measure could prepare the sector to move to a single licence, which would probably spur competition in different telecommunication service markets, allow operators to reap economies of scope and increase the variety of services offered, thereby raising consumer welfare.

The market for telecommunication services is separated into two distinct regimes and suffers from a lack of competition in the fixed-line segment. In the "public" regime, which is restricted to the fixed-line segment, firms have to achieve universal service targets, comply with price caps and fulfil service obligations and accounting separation. There is usually one dominant player per state. This regime is set to expire by 2025 and is to be reviewed by 2015. Under the "private regime", firms operate under minimum intervention from the government and prices are free. There is no restriction on foreign investment in the private regime. Although reforms have sought to foster competition and product market structure appears to be more competitive in Brazil than in many OECD economies (Figure 9), the fixed-line sector is dominated by only a few enterprises (IPEA, 2010b). Firms usually benefit from a monopoly in their concession areas, as they have full control over the use of their infrastructure network. There is no regulation that defines the conditions under which a firm can exploit a competitor's network. The authorities should take the opportunity of the 2015 review to reassess the costs and benefits of maintaining the current dual system, given the difficulty of injecting competition in market segments under concessions. If it is found useful to maintain the two regimes, the authorities should lower entry barriers 
and issue regulations that clarify the conditions under which a competitor can rent existing fixed-line infrastructure.

There is some scope to finance universal service obligations (USOs) in a more cost-effective manner. The Fundo de Universalização dos Serviços de Telecomunicações (FUST) was established in 2000 to finance USO targets and is funded through a 1\% tax on telecommunication companies' revenues. This adds to the already high tax burden, which amounts to around $40 \%$ and is eventually passed on to customers. However, only BRL 10 out of 756 million of FUST revenues are actually used to finance USOs. The rest lies in Treasury accounts. The government should quickly remedy this situation by developing a clear investment plan of FUST's resources. Moreover, given the dominant role played by the service provider in the public area, it is unclear whether the current system provides the right incentive to minimise USO costs. Allocating subsidies to extend services in underserved areas through auctions where both the private and public regimes could compete would be a way to minimise these costs.

Figure 9. Product market regulation in telecommunications

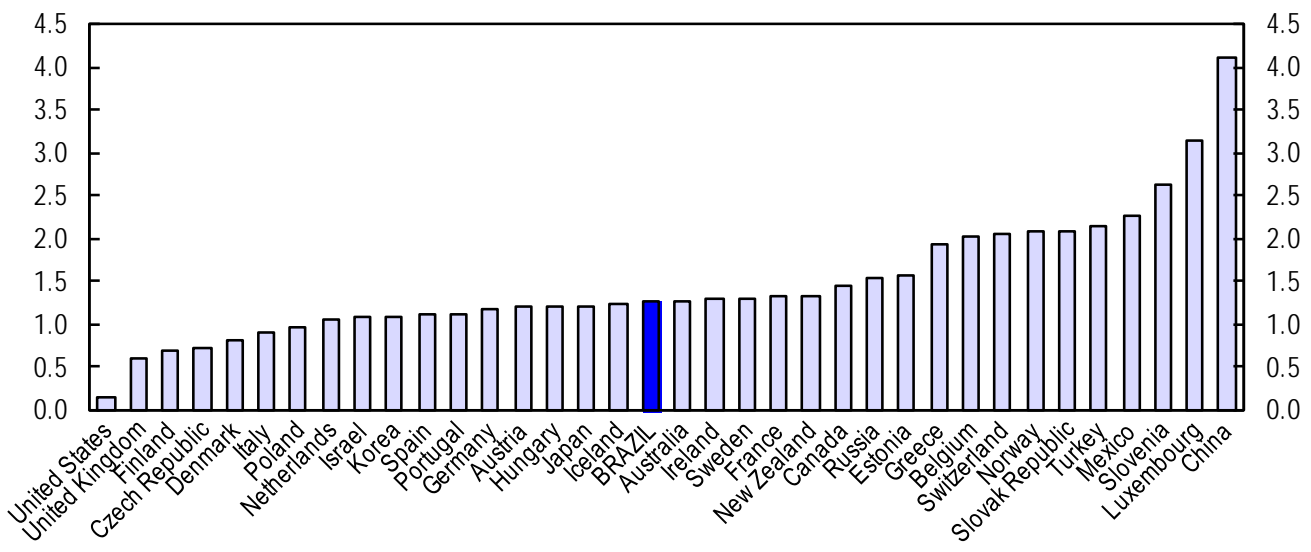

Note: The indicator ranges between 0 (less restrictive) to 6 (more restrictive).

Source: OECD.

\section{Land transport}

\section{Railways}

Despite its huge potential, the Brazilian railway sector is underdeveloped and underexploited. Tight control by the federal government over tariffs until the late 1980s led to impaired financial conditions of railway operators and resulted in severe underinvestment and low maintenance spending (Estache et al., 2001). This has produced a rather singular phenomenon: the total length of the railway network shrank from 34207 kilometres in 1930 to 29637 in 2009 (ANTT, 2010; da Silva Campos Neto et al., 2010). Railways are used only to transport merchandise. A first high-speed passenger line between Rio de Janeiro and São Paulo is currently under consideration, but because of the lack of private-sector interest, the project has been delayed.

The Ministry of Transport (MoT) and the regulatory authority Agência Nacional de Transportes Terrestres (ANTT), created in 2001, have joint responsibilities over the railway sector. The MoT is responsible for setting long-term railway-transport policies and guiding the development of the sector. The 
main responsibilities of ANTT involve the definition of rights and duties of users and railway operators, managing railway interconnections and joint transport, specifying penalties for missing output and safety targets and reviewing output and safety targets every five years. Another important player in the sector is the public-sector company, Valec Engenharia Construções e Ferrovias. It is in charge of constructing rail tracks, promoting feasibility studies on high-speed trains and signing contracts and agreements with national administration bodies, private companies and international organisations to implement investment projects. In addition to Valec, there are four large groups in the sector, each enjoying a regional monopoly.

The railway transportation system was privatised in the mid-1990s. The impact of privatisation on operational outcomes has been by and large positive (Estache et al., 2001). Productivity increased as the labour force was reduced. Although profitability continued to vary considerably among railway companies, with some even posting losses, the subsidies paid by the federal government decreased drastically. Yet, privatisation has not eliminated all bottlenecks hindering the development of the sector. The prospect of huge sunk costs still deters private investment.

One major issue is to expand the network, given the significant social externalities associated with railway transport and its smaller greenhouse gas (GHG) emissions relative to road transport. PAC allocates BRL 43.9 billion to the railway sector for the 2011-14 period, of which less than $30 \%$ will be financed by the public sector. The decision to increase public investment in railways in a context of fiscal consolidation is welcome, given the large long-term pay-offs associated with this type of investment. The authorities should continue to protect cost-effective projects in railways from budget cuts.

The sector would benefit from additional private investment. Improving the business environment is likely to foster such investment. At the moment only the public company Valec has been granted the right to expand the network. Relying on a public company makes sense, given the very high sunk cost and the large externality of building the rail network. However, changes could also be made to the content of concession contracts, which have constituted up to now the only form of private-sector participation. These contracts include output and safety objectives aiming at improving and renovating the existing network and rolling stock. These targets are commendable from a regulatory point of view, as they let the authorities set some welfare-enhancing objectives while allowing private operators to identify the most cost-effective ways to achieve them. However, they have not succeeded in spurring maintenance outlays. It would be useful to specify clear maintenance spending targets in concession contracts to improve the quality of the railway network.

Limited interconnectivity among the networks under different concessions unduly limits the return on investment to extend the rail network and therefore prevents the much needed enlargement of Brazil's railway system (da Silva Campos Neto et al., 2010). The privatisation process has conferred on vertically-integrated railway companies a monopoly over relatively disconnected rail tracks extending over the East-West axis. However, growing North-South traffic has made it clear that concessionaires are obliged to increasingly use other concessions' tracks to expand their services and reach new destination markets. To ensure a minimum degree of interconnectivity, concessionaires are expected to undertake joint transport, whereby the cargo of a railway company is loaded and carried by the concessionaire of the network through which it needs to be transported, upon payment for the transport services. If this is not possible, concessionaires should grant access to their network, upon payment of a fee. In case the parties do not find an agreement the Ministry of Transport could impose compulsory tariffs. This system has, however, failed to produce smooth network interconnections, partly because of physical constraints (tracks' gauge may differ across networks) and insufficient regulation. Setting ex ante compulsory interconnection fees at cost-recovery levels is likely to lower the probability of disputes between concessionaires over connecting rail tracks in different concession areas. 
Roads

Brazil's road system is inadequate to the country's needs. Although the network of around 1.7 million kilometres is one of the longest in the world, the share of paved roads was only $13.8 \%$ in 2008, with large disparities across states (Figure 10). The poor state of the system is likely to impinge more negatively on Brazil's competitiveness and economic growth than in other countries as around $60 \%$ of freight is transported by lorries (Ministério dos Transportes, 2007). This share is much higher than the corresponding figure of most other continental-sized countries such as the United States (35\%), Russia (5\%) and China (20\%). There is evidence that low-quality roads raise transport costs on average by $28 \%$ compared to what they would be under ideal road conditions (CNT, 2010; Resende, 2006). Poor-quality roads are particularly pervasive in the North and the Northeast regions. Data suggest that states that invested more in road infrastructure also experienced stronger increases in GDP per capita from 2000 to 2008.

Figure 10. Percentage of paved roads

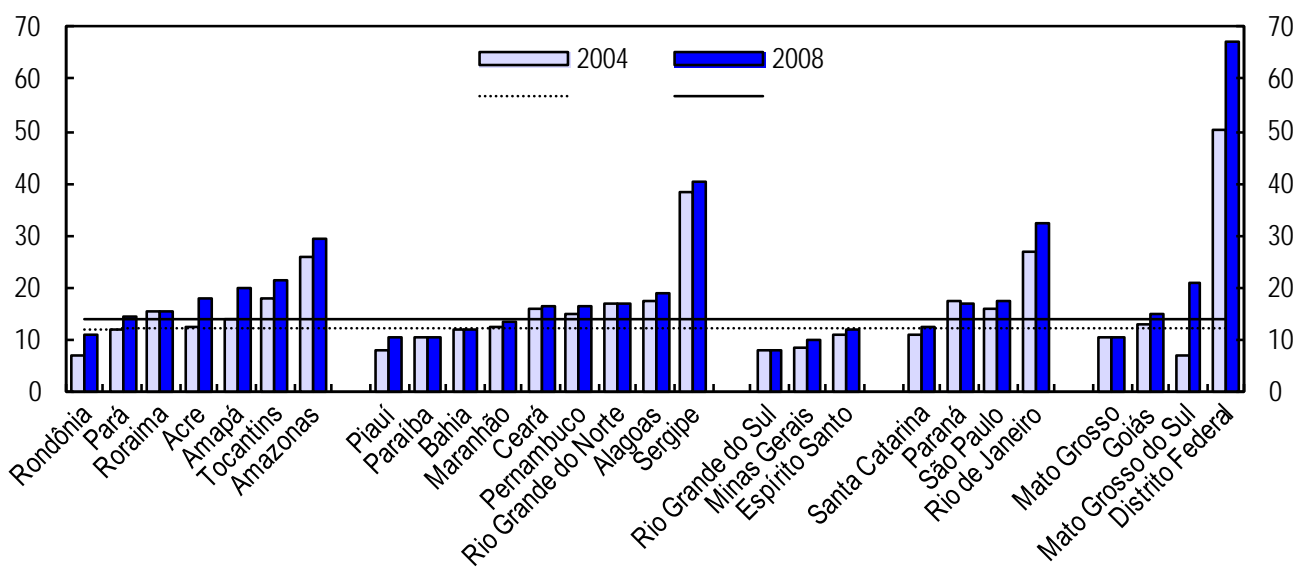

Note: The lines represent the Brazilian average.

Source: ANTT.

To rehabilitate the road sector, the government began to sign road concession agreements in the 1990s, mostly for 25-year periods. At the end of 2009, around 50 concessionaires managed 14993 kilometres of the road network. Of the total roads conceded, 32\% are owned by the federal government and the rest by state governments. A recent survey (Pesquisa Rodovias) reports that $87.3 \%$ of highways under private concessions are in good or very good condition, whereas the corresponding figure for those under the responsibility of public authorities is just 32.4\% (CNT, 2010).

The way contracts are written at the moment does not encourage concessionaires to undertake investments to improve or expand toll roads. This issue arises as the main criterion currently used to award federal road concessions is based on the lowest toll charged. Winners are expected to undertake rehabilitation works at the beginning of the concession period and ordinary maintenance until the concession expires. But clauses in existing contracts are sometimes vague. To overcome this problem the government should spell out precise investment targets in concession contracts aiming at significantly extending and improving roads over the entire life of the concession and not just at rehabilitating and maintaining them. Specifying such targets and keeping the current allocation system based on the lowest tariffs may be infeasible. The authorities could explore the use of alternative awarding criteria such as the Least Present Value of the Revenues mechanism (LPVR). With this option, the winning bid would be the one offering the least present value of the accumulated revenues - using a pre-determined discount rate 
that reflects the weighted average cost of capital. The experience of Chile with this scheme since 1998 has been positive (Box 2).

\section{Box 2. The experience of Chile with the Least Present Value of the Revenues mechanism}

The Least Present Value of the Revenues (LPVR) method to award concession contracts in the road sector was developed by Engel, Fischer and Galetovic (1997 and 2001) following a proposal from the Chilean Ministry of Public Works. Chile awarded the first concession on the basis of this selection criterion in 1998. LPVR eliminates the demand-side risk as the concession period ends when LPVR is reached. If the traffic is ultimately higher than projected, the concession will end earlier. On the other hand, if it is lower the concession will finish later. Using the LPVR, bidders disclose the revenue they require to meet their targeted return on investment. This discourages artificially low bids and reduces the scope for renegotiations during the life of the contract. Another substantial advantage is that public authorities may reserve the right to buy out the concession by paying the concessionaire the difference between the LPVR and the revenues already accrued. Besides putting a ceiling on government's contingent liability, this allows the public authority to end the contract instead of renegotiating it.

Source: Vassallo (2006)

\section{Water and sanitation}

Water and sanitation is the sector where investments are probably the most needed. The situation is particularly critical for sewerage, as only $47 \%$ of the population - concentrated in the South-Southeast region - benefit from sewage collection and approximately $20 \%$ of collected sewage is treated. It is estimated that an investment of BRL 22 billion will be necessary to prevent $55 \%$ of the municipalities, including large ones like São Paulo or Rio de Janeiro, from facing water shortages by 2015 (ANA, 2011). Accordingly, the government has rightly indicated it will direct more resource to the sector via the second step of the programme My House My Life (Minha Casa, Minha Vida). Within PAC, investments for the period 2011-14 are estimated to be 92\% higher than those during 2007-10. In addition the federal government has encouraged municipalities to invest in the sector.

The current framework was established in 2007. Past regulatory structures ranged from a totally decentralised framework to a fully centralised one (Planasa) and performed poorly, in part because of the unstable macroeconomic environment, but also because they lacked specific guidelines on tariff policy. The 2007 law filled this gap. In addition, it granted regulatory authorities administrative and financial independence. It also strengthened public accountability mechanisms of the planning and decision-making process in the sector by means of public hearings and consultation with all stakeholders. The new regulatory framework is well thought out overall and has the potential to increase investment in the sector by explicitly addressing issues that have beset it for a long time, especially the financial and economic sustainability of water and sanitation service provision.

The sector is highly decentralised: municipalities are responsible for service provision, and states oversee large urban agglomerations to exploit available scale economies and cross-subsidise poor municipalities. Sub-national entities responsible for the local water and sanitation sector can delegate the organisation, regulation and provision of such services to public or private companies or consortia, but in practice, private participation in the sector is very limited. The federal government has mainly a co-ordinating role. It is tasked with developing the national basic sanitation plan (which sets targets to achieve universal access in the whole country and other guiding principles) that local sanitation plans have to follow. Decentralisation poses a trade-off between locating supply and management decision-making near the source of demand and creating co-ordination challenges among different local authorities. Still, international experience shows that Brazil's decentralised system should not be viewed as an obstacle to reaching universal coverage of high-quality water and sanitation services. Alternative systems relying on a 
single utility managing several or all of a country's water and sanitation services, rural and urban, have not been more effective in extending service coverage than more decentralised structures (Clarke and Wallsten, 2002; Kessides, 2004).

Wide variations exist in local service coverage and in quality of service provision across regions, reflecting differences in sub-national administrative capacity and the ability to pay of the local population. To address this issue, the federal regulatory agency for water resources (Agência Nacional do Agua, ANA) has put in place special programmes to increase the management capabilities of municipalities. In addition, the federal government has recently devised a Federal Sanitation Plan, with the objective of guiding municipalities in the nature and the sequencing of reforms. These initiatives are useful and should be pursued. The federal government should also set guidelines defining minimum quality-of-service requirements to improve service quality and coverage in laggard jurisdictions.

Ensuring that water and sanitation services' supply satisfies increasing demand requires institutional arrangements that simulate a competitive environment. Competition in the sector is arguably difficult because of the existence of natural monopoly. Exclusivity rights are usually granted to water and sanitation utilities to make concession contracts more attractive to potential investors or permit the service provider to cross-subsidise customers. Yet, exclusivity may not produce the expected social benefit where water coverage is low and utility performance poor. Easy regulators' and consumers' access to information on performance levels and quality of services of utilities may strengthen incentives for efficiency and make it possible to formally introduce yardstick competition. The federal government already collects a substantial amount of data on different aspects of water and sanitation operations, which should make implementing yardstick competition an achievable target. Local governments could make use of this detailed information and introduce performance-based penalties and rewards to create incentives to reach minimum service quality and coverage and promote best practice.

Water and sewerage tariffs vary widely between cities and regions (Figure 11). Regulatory agencies define the tariff regime and specify the mechanisms to revise tariffs at periodic intervals. Tariffs must be set at cost-recovery levels and should allow for the necessary investments to expand service coverage and guarantee an appropriate remuneration of the capital invested. In most cities, a low social tariff applies to the first block of consumption in order to support low-income households. In some cases, the targeting of social tariffs has been improved by using registers from the Bolsa Familia programme, but in most cases the targeting remains poor. In addition, the resulting cross-subsidies among users can be detrimental to the efficiency of service delivery, while not helping to address inequality. Indeed, cross-subsidies can hinder network expansion in rural and poor areas as revenues may not cover the costs of extending the network therein. At the same time, cross-subsidies do not always benefit poorer households, who do not necessarily have access to the network, especially in remote areas in the North of the country. Against this background, the federal government plans to provide financial incentives to water companies to expand the network and to offer a subsidised tariff to poor households. It is also seeking to improve the targeting by making more systematic use of Bolsa Familia's registries. This initiative is likely to be effective in increasing access to water and sanitation services to needy households and should be implemented as soon as possible.

Consolidation of small-scale water and sanitation operations merits attention. Brazil's water and sanitation providers are extremely heterogeneous in size and economic performance. The average number of connections was 62490 for water and 47611 for sewerage in 2008, but this figure masks considerable variation. It is likely that small establishments incur large costs because of the lack of economies of scale. Such economies are substantial for establishments serving up to 125000 households and become weaker for those with more than 250000 (World Bank, 2007). This suggests that renewed efforts might be needed to raise the size of water and sanitation establishments by merging the smallest and rationalising their operations. One way to consolidate water utilities could be to merge them by river basins. The Consortium 
Law passed in 2005 is a step in the right direction, as it sets an appropriate legal framework allowing municipalities to share their water and sanitation services. Nine consortia have been created in the area of public sanitation. However, to date there do not exist enough incentives for municipalities to form consortia, especially for water and sanitation companies in surplus to merge with those in deficit.

Figure 11. Average water tariff

$\mathrm{BRL} / \mathrm{m}^{3}, 2008$

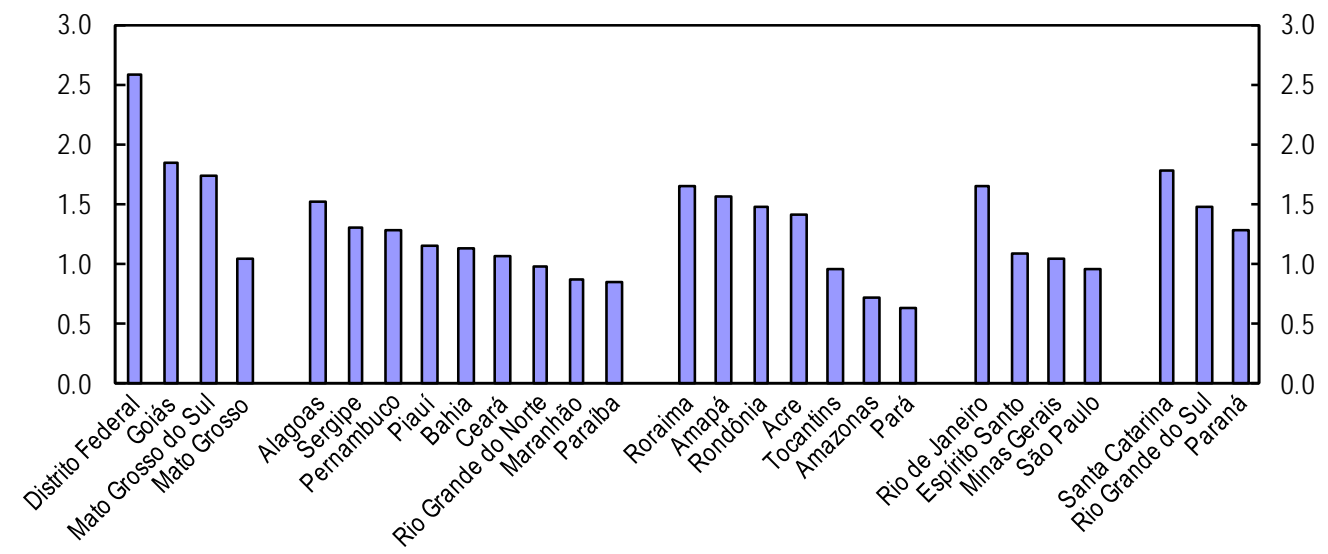

Source: Ministry of Cities, Sistema national de informações sobre saneamento - SNIS.

One reason for the lack of investment in the sector is the high level of debt of certain municipalities, which puts them at risk of not complying with the Fiscal Responsibility Law. This problem is not easy to solve as the water and sanitation law forbids the federal government from allocating budget resources for the operation and maintenance of water and sanitation services not administered by a federal agency or entity, except in case of imminent risks to public health and the environment. But the federal government can (and has) provide(d) special loans through the state bank Caixa Econômica Federal (CEF) to help municipalities in financial difficulty. This policy appears to be useful, but the federal government could envisage making such loans conditional on reforming service providers' structure and making their operations financially viable, for instance by forming a consortium. This might provide stronger incentives to achieve available scale economies.

\section{Conclusion}

After more than three decades of underinvestiment, Brazil's infrastructure investment needs are sizeable in almost all sectors. Public infrastructure spending has been growing at an increasing though moderate pace since the turn of the millennium to reach $2.1 \%$ of GDP in 2009. Higher investment rates in infrastructure are paramount to sustain fast economic growth and convergence in living standard with OECD countries. At its current stage of development, infrastructure investment in Brazil is likely to have large payoffs. Brazilian authorities are aware of this challenge and have launched a large infrastructure plan named Growth Acceleration Programme (Programa de aceleração do crescimento, PAC) with the aim of boosting public and private infrastructure spending and making it more effective.

The regulatory and legal framework of infrastructure sectors is well established and working reasonably well. However, different ameliorations could be introduced to make public investment more cost-efficient and to increase further private participation. More specifically, although PAC is a laudable and worthwhile initiative, its coverage is too wide and it will be important to focus on completing the most worthwhile projects. Besides raising investment rates in infrastructure, adequate levels of operation and 
maintenance spending should be ensured to preserve the infrastructure stock. For this purpose, the authorities could set specific rules to quantify the yearly operation and maintenance costs of existing and planned infrastructure, and incorporate them in multi-year budgets.

In order to foster private participation, the PPP framework could be streamlined, by consolidating responsibilities among the numerous authorities involved in the selection process. Frequent disputes still delay the completion of projects, especially in the energy sector, thus discouraging private investment. The main challenge in this area is to accelerate the licensing process, while keep ensuring suitable environmental and social protection. In this respect, adopting comprehensive rules concerning the compensation payments to populations affected by infrastructure projects would lower costly uncertainty regarding such compensation and shorten the time needed to determine them.

At the sectoral level, a number of changes are also likely to spur investment rates:

- In the electricity sector, an evaluation of the state of competition is needed and actions should be taken to prevent cross-subsidisation across customers, if needed. It will be also useful to assess whether or not there is room to increase competition in generation, which is currently dominated by the public-owned enterprise Eletrobrás.

- The telecommunication sector is characterised by a dual system with different price-setting regulations and operators' service obligations and there is evidence of a lack of competition in the fixed-line segment. It is opportune to review the costs and benefits of such a dual system and, if it is find appropriate to maintain this dual system, specify the conditions under which a firm can exploit an existing network. The sectoral regulator, ANATEL, and the Ministry of Telecommunications need to better coordinate their work and operations so as to meet the requirement of service convergence.

- The railway sector is underdeveloped and underexploited. Remarkably, the total length of the railway network shrank from 1930 to 2009 as a result of tight control by the federal government until the late 1980s and low maintenance spending. Large investments are needed to reverse this trend. PAC duly allocates to the railway sector substantial resources over the 2011-14 period. Given their large economic and environmental payoffs, the authorities should keep protecting spending on cost-effective projects from budget cuts. There is ample room to improve the interconnection between different railway-licence areas, by setting up ex ante compulsory interconnection fees.

- The road system is inadequate to the country's needs. Although the road network is one of the longest in the world, the share of paved roads is low (less than 15\%). This impinges negatively on Brazil's competitiveness and economic growth as a large share of freight is transported by lorries. To re-habilitate the road sector, the government started signing road concession agreements in the 1990s. This strategy has borne fruits in terms of road quality. However, presently concession contracts do not provide incentives to undertake investments, in addition to those necessary to rehabilitate roads, in order to improve or expand toll roads. To overcome this problem the government should set precise investment targets in concession contracts aiming at significantly extending and improving roads over the entire life of the concession and not just at rehabilitating and maintaining them.

- Water and sanitation is probably the sector where investments are most needed, especially in sewerage. The government is aware of the problems facing the sector and it has indicated it will devote more resource to the sector while encouraging municipalities to invest more in the sector. In this regard, the federal government could make loans to municipalities conditional 
on forming consortia for the management of water and sanitation services where this would yield economies of scale. The efficiency of water and sanitation utility needs to improve. Introducing penalties and rewards for the worst and best performances would generate strong incentives for utilities to improve their performance. The water and sanitation network also needs to be enlarged. The plan of the federal government to grant operators a subsidy to expand the network and enhance service affordability to the poor is likely to be a more efficient way to support low-income households than the existing social tariffs and should be executed swiftly. 


\section{Bibliography}

ABCR (2010), Annual Report 2009, Associação Brasileira de Concessionárias de Rodovias, http://www.abcr.org.br/publi/pub_relatorio.php, accessed November 2010.

Afonso, J.R.R., E. Amorim Araújo and G. Biasoto Júnior (2005), "Fiscal Space and Public Sector Investments in Infrastructure: A Brazilian Case-Study”, IPEA Texto para Discussão No. 1141, IPEA, Rio de Janeiro.

ANA (2011), Atlas Brasil - Abastecimento Urbano de Água, March, Brasilia.

ANTT (2010), Evolução Recente do Transporte Ferroviario, http://www.antt.gov.br/concessaofer/EvolucaoFerroviaria.pdf, accessed November 2010.

Arnold J. (2011), Raising saving and investment in Brazil, OECD Economics Department, forthcoming.

BNDES (2011), “Perspectiva de investimentos em infraestrutura 2011-2014”, Visão do Desenvolvimento No. 92, February, Brasilia.

Calderón, C. and L. Servén (2010), "Infrastructure in Latin America”, World Bank Policy Research Working Paper, No. 5317, May, Washington, D.C.

Clarke, G. and S. Wallsten (2002), “Universal(ly Bad) Service: Providing Infrastructure Services to Rural and Poor Urban Consumers”, Policy Research Working Paper No. 2868, World Bank, Washington, D.C.

CNT (2010), Pesquisa CNT de Rodovias 2010, http://www.cnt.org.br, accessed November 2010.

Correa, P., C. Pereira, B. Mueller and M. Melo (2006), "Regulatory Governance in Infrastructure Industries - Assessment and Measurement of Brazilian Regulators", Trends and Policy Options No. 3, World Bank, Washington, D.C.

Égert, B., T. Kozluk and D. Sutherland (2009), "Infrastructure Investment: Links to Growth and the Role of Public Policies”, OECD Economics Department Working Papers, No. 686.

Engel, E., R. Fischer and A. Galetovic (1997), 'Highway Franchising: Pitfalls and Opportunities', American Economic Review, 87, 68-72.

Engel, E., R. Fischer and A. Galetovic (2001), 'Least Present Value of Revenue Auctions and Highway Franchising”, Journal of Political Economy, 109, 993-1020.

Estache, A., A. Goldstein and R. Pittman (2001), "Privatization and Regulatory Reform in Brazil: The Case of Freight Railways”, Journal of Industry, Competition and Trade, 1(2), 203-35.

Estache, A. and M. Fay (2007), “Current Debates on Infrastructure Policy”, Policy Research Working Paper No. 4410, World Bank, Washington, D.C. 
Ferreira, P. and C. Araújo (2010), “Growth and Fiscal Effects of Infrastructure Investment in Brazil”, Fundação Getulio Vargas, http://www.fgv.br/professor/ferreira/BrazilInfra4.pdf, accessed February 2011.

Guasch, J.L, J. Laffont and S. Straub (2003), "Renegotiation of Concession Contracts in Latin America”, Policy Research Working Paper, No. 3011, World Bank, Washington, D.C.

Guasch, J.L., J. Laffont and S. Straub (2007), “Concessions of Infrastructure in Latin America: Government-led Renegotiation”, Journal of Applied Econometrics, 22(7), 1267-94.

IPEA (2010a), Brasil em Desenvolvimento 2010, Volume 1, Chapter 4, 121, Brasilia.

IPEA (2010b), "Rodovias Brasileiras: Gargalos, Investimentos, Concessoes e Preocupaçoes com o Futuro", Comunicados do IPEA, No. 52, Rio de Janeiro.

IPEA (2010c), Infraestrutura e Econômia no Brasil: Diagnósticos e Perspectivas para 2025, Livro 6, Volume 1, Brasilia.

Kessides, I.N. (2004). Reforming Infrastructure: Privatization, Regulation, and Competition, World Bank, Washington, D.C.

López, H. (2004), "Macroeconomics and Inequality”, The World Bank Research Workshop, Macroeconomic Challenges in Low Income Countries, October, Washington, D.C.

de Mello, L. and D. Moccero (2006), "Brazil's Fiscal Stance during 1995-2005: The Effect of Indebtedness on Fiscal Policy Over the Business Cycle”, OECD Economics Department Working Papers, No. 485.

Ministério de Minas e Energia and EPE (2010), Plano Decenal de Expansão de Energia, Brasilia.

Ministério dos Transportes (2007), Plano Nacional de Logística \& Transportes, http://www.transportes.gov.br/PNLT/CD_RE/, accessed November 2010.

Morgan Stanley (2010), “Brazil Infrastructure: Paving the Way”, Morgan Stanley Blue Paper, May.

OECD (2008), OECD Reviews of Regulatory Reform - Brazil: Strengthening Governance for Growth, OECD Publishing, Paris.

OECD (2009), Telecommunications Outlook, OECD Publishing, Paris.

OECD (2010), OECD Integrity Reviews: Brazil: Managing Risks for a Cleaner Public Service:

Preliminary Main Findings and Proposals for Action, OECD Publishing, Paris.

OECD (2011), Recent Experiences with Structural Separation, forthcoming, Paris.

Pires, J.C. and A. Goldstein (2001), “Agências Reguladoras Brasileiras: Avaliação e Desafios”, Revista do BNDES, 8(16), 3-42.

Resende, P. (2006), Notes on the Current Conditions of the Brazilian Logistics Infrastructure, Fundação Dom Cabral, Nova Lima. 
Seroa da Motta, R. and A. Moreira (2006), "Efficiency and Regulation in the Sanitation Sector in Brazil”, Utilities Policies, 14, 185-95.

da Silva Campos Neto, C.A., B. Pêgo Filho, A.E. Romminger, I. Melo Ferreira and L.F. Soares Vasconcelos (2010), “Gargalos e Demandas da Infraestrutura Ferroviária e os Investimentos do PAC: Mapeamento IPEA de Obras Ferroviárias”, IPEA Texto para Discussão No. 1465, Rio de Janeiro.

Stern, J. (2007), "Evaluating Regulatory Decisions and Sector Outcomes in Infrastructure Industries: Results from Africa and other Developing Countries”, PPIAF Working Paper No. 3, World Bank, Washington, D.C.

Straub, S. (2008), "Infrastructure and Growth in Developing Countries: Recent Advances and Research Challenges”, Policy Research Working Paper No. 4460, World Bank, Washington, D.C.

Vassallo, J.M. (2006), “Traffic Risk Mitigation in Highway Concession Projects“, Journal of Transport Economics and Policy, Vol. 40(3), 359-81.

World Bank (2007), Brazil: How to Revitalize Infrastructure Investments in Brazil: Public Policies for Better Private Participation, Report No. 36624-BR, Washington, D.C.

World Bank (2008), Environmental Licensing for Hydroelectric Projects in Brazil: A Contribution to the Debate, Report No 40995-BR, Washington, D.C. 


\section{WORKING PAPERS}

The full series of Economics Department Working Papers can be consulted at www.oecd.org/eco/workingpapers/

897. Austria: public sector inefficiencies have become less affordable

(October 2011) by Karin Fischer, Rauf Gönenç and Robert Price

896. Informality in Mexico

(September 2011) by Nicola Brandt

895. Reforming Austria's highly regarded but costly health system

(September 2011) by Rauf Gönenç, Maria. M. Hofmarcher, Andreas Wörgötter

894. Greener growth in the Belgian federation

(September 2011) by Tomasz Koźluk

893. Green growth and climate change policies in New Zealand

(September 2011) by Alexandra Bibbee

892. Has deregulation increased investment in infrastructure? Firm-level evidence from OECD countries

(September 2011) by Sónia Araújo

891. Ensuring a Sustainable and Efficient Fishery in Iceland

(September 2011) by Gunnar Haraldsson and David Carey

890. Japan's New Growth Strategy to create demand and Jobs

(September 2011) by Randall S. Jones and Byungseo Yoo

889. Labour market reforms in Japan to improve growth and equity

(September 2011) by Randall S. Jones and Satoshi Urasawa

888. Education reform in Japan

(September 2011) by Randall S. Jones

887. The Political Economy of Climate Change Mitigation Policies: How to Build a Constituency to Address Global Warming?

(August 2011) by Alain de Serres, John Llewellyn and Preston Llewellyn

886. Climate-Change Policy in the United Kingdom

(August 2011) by Alex Bowen and James Rydge

885. Improving Access and Quality in the Indian Education System

(August 2011) by Sam Hill and Thomas Chalaux

884. How Institutions Shape the Distributive Impact of Macroeconomic Shocks: A DSGE Analysis

(July 2011) by Rudiger Ahrend, Charlotte Moeser and Tommaso Monacelli

883. Can India Achieve Double-Digit Growth?

(July 2011) by Richard Herd, Paul Conway, Sam Hill, Vincent Koen and Thomas Chalaux 
882. Predicting peaks and troughs in real house prices

(July 2011) by Linda Rousová and Paul van den Noord

881. Public sector spending efficiency in Estonia: healthcare and local government (July 2011) by Zuzana Smidova

880. How to move Product Market Regulation in New Zealand back towards the frontier (July 2011) by Paul Conway

879. Financial sector reform in India: time for a second wave?

(July 2011) by Richard Herd, Vincent Koen, Ila Paitnak and Ajay Shah

878. Policies to rebalance housing markets in New Zealand (July 2011) by Calista Cheung

877. The sharing of macroeconomic risk: Who loses (and gains) from macroeconomic shocks (July 2011) Rudiger Ahrend, Jens Arnold and Charlotte Moeser

876. Estonia: making the most of globalisation (June 2011) Robert Price and Andreas Wörgötter

875. The effects of downturns on labour force participation: evidence and causes (June 2011) Romain Duval, Mehmet Eris and Davide Furceri

874. A dynamic factor model for world trade growth (June 2011) Stéphanie Guichard and Elena Rusticelli

873. Towards a better understanding of the informal economy (May 2011) Dan Andrews, Aida Caldera Sánchez and Åsa Johansson

872. Tax competition between sub-central governments (May 2011) Hansjörg Blöchliger and José-Maria Pinero-Campos

871. The growth effects of current account reversals: the role of macroeconomic policies (May 2011) Luiz de Mello, Pier Carlo Padoan and Linda Rousová

870. Les politiques du logement en France (May 2011) Bénédicte Rolland

869. How important is wealth for explaining household consumption over the recent crisis? An empirical study for the United States, Japan and the euro area (May 2011) Clovis Kerdrain

868. Adjusting fiscal balances for asset price cycles (May 2011) Robert Price and Thai-Thanh Dang

867. Improving the functioning of the housing market in the United Kingdom (May 2011) Christophe André

866. An analysis of demand for foreign exchange reserves (May 2011) Peter Vujanovic 